\title{
ERRATUM
}

The article by Professor Stephen A. Scott, The Supreme Court and Civil Liberties, on page 97 of volume 14-1 contains a printing error. The first sentence of the article should end with the word "GIFT" rather than the words "power to give". The corrected sentence would thus read-Judged by the maxim "Choose wisely and confide liberally", it cannot be denied that the Parliament of Canada has lavished upon the Supreme Court that general appellate judicial power which the Imperial Acts of 1867 and 1931 put within its GIFT.

The article by Stephen Allan Scott, entitled The Supreme Court and Civil Liberties, must in all circumstances be cited: (1976) 14 Alberta Law Review iii and 97.

The Alberta Law Review wishes to apologize to the author for this unfortunate error. 


\section{THE SUPREME COURT AND CIVIL LIBERTIES}

\section{STEPHEN ALLAN SCOTT*}

Of the plan suggested by its title (intended to embrace amongst other things some treatment of the Canadian Bill of Rights and relevant aspects of the distribution of legislative authority) this paper as delivered is confined to a single part dealing with the rule of law. Roncarelli $v$. Duplessis, probably the single most celebrated of the Supreme Court's decisions, is chosen as the source of four themes. Each involves conflict between the individual's rights and liberties and governmental power. The author argues that lawful governmental action - especially competent legislation and anything which is authorized by competent legislation - is damnum sine injuria. Some of the harshest consequences of legislative supremacy have however been mitigated by various common law rules, notably those governing natural justice, the prerogative remedies, mens rea in the criminal law, the condition of reasonableness implied into at least some statutory powers, and the restriction of subdelegation. The author examines critically the work of the Supreme Court on these subjects, as also on the matter of access to the courts for redress, a question central to individual liberty, both as regards the jurisdiction of the Supreme Court of Canada itself, and that of the other superior courts.

\section{INTRODUCTION}

Judged by the maxim "Choose wisely and confide liberally", it cannot be denied that the Parliament of Canada has lavished upon the Supreme Court that general appellate judicial power which the Imperial Acts of 1867 and $1931^{1}$ put within its power to give. The thirty-fifth section of the Supreme Court Act $^{2}$ boldly provides that "The Supreme Court shall have, hold and exercise an appellate, civil and criminal jurisdiction within and throughout Canada." The fifty-fourth restates the law - this time speaking specially to the ultimate character of the court's authority:

The Supreme Court shall have, hold and exercise exclusive ultimate appellate civil and criminal jurisdiction within and for Canada; and the judgment of the Court is, in all cases, final and conclusive.

The phrases roll in the grand manner (the changing tense of course excepted); nothing here of the dull and unromantic hand which has struck the denizen. ${ }^{3}$ And if the statute book testifies for itself to legislative deference to the injunction to confide liberally, we for our part, were we to doubt the executive government's correlative wisdom in choice, should surely be ungenerous to the distinguished judges who have so graciously agreed to take part in our meetings. More particularly do we owe our thanks to my Lord the Chief Justice

- Of the Bar of the Province of Quebec and the Faculty of Law, McGill University.

1 The British North America Act, 1867, 30 \& 31 Vict., c. 3 (U.K.), s. 101, read especially with Crown Grain Company, Limited v. Day [1908] A.C. 504 (P.C.); and The Statute of Westminster, 1931, 22 Geo. V, c. 4 (U.K.), ss. 1, 2, 3, and 7, read especially with A.-G. Ontario v. A.-G. Canada [1947] A.C. 127 (P.C.) (the reference respecting abolition of appeals to the Queen in Council).

2 R.S.C. 1970 , c. S-19, as amended.

s Section 6 of the Canada Shipping Act, R.S.C. 1952, c. 29, under which a denizen was qualified to be the owner of a British ship, was repealed and replaced by An Act to amend the Canada Shipping Act, 9-10 Eliz. II, S.C. 1960-61, s. 3. Some people, clearly, have no sense of humour. Quaere, whether any legal incident of denization survives anywhere in Canada; whether the Crown has ever issued letters of denization in right of Canada or in respect of Canada; and whether the prerogative is exercisable by the Governor-General under Article II of the royal Letters-Patent of 8th September, 1947. 
of Canada here present - a judge of not fewer than three courts. ${ }^{4}$ Still, the work of the Supreme Court of Canada must be able to withstand candid, and even vigorous, criticism. Intra familiam it may be hoped that even a measure of irreverence can be forgiven.

An invitation to review the work of the Supreme Court in connection with "civil liberties" - or "human rights" - or "public liberties" - cannot easily be resisted. Yet it is no mean task. In 1877 one James Paterson published in London two volumes on The Liberty of the Subject and the Laws of England relating to the Security of the Person. He wrote with some considerable advantages. He was not only a Barrister-at-Law but also "Sometime Commissioner for English and Irish Fisheries, etc.". His introductory chapters encompassed concepts and definitions of law, ancient and modern, and proposed " $A$ New Tenfold Division of Law". ${ }^{3}$ Four chapters on the protection of the body dealt with injuries threatened, apprehended, and actual, - intentional as well as negligent, both malicious and otherwise. These ranged from challenges to fight through the acts of vicious animals to the negligence of servants. The sumptuary laws received passing attention in a chapter on "Restrictions Owing to Compulsory Acts and Duties Strictly Personal". "The Protection of the Body against Want and Destitution" embraced poor laws, vagrants, begging, rating of property, and removal and settlement of paupers. Two chapters on criminal law preceded four on "variations" in rights, duties and obligations, caused respectively by age; by sex; by insanity and defective understanding; and by death. In the second of these one could learn, for example, about protection of women's chastity, contagious diseases, unfit trades and occupations of women, and punishments of women. The last chapter covered amongst other things respect for the dead, extravagant expense of funerals, dissecting the dead, the duty to bury dead bodies, burial in churchyards, burial service, tombs, and the enlargement of burial grounds.

At a gathering of the Association of Canadian Law Teachers it would be invidious to dwell on the sumptuary laws. Similarly, too close a scrutiny of the chasity of women might be misunderstood. Even so, there is a good deal left for our attention, especially if, like Dicey, we look upon liberty as the residual freedom remaining after deduction is made for our duties and liabilities. Still, Canadian law teachers do not cower at challenges. Bravely putting aside, if we can for a moment, our preoccupation with the hazards presented by negligent servants and vicious animals, we can surely find some themes which can profitably be explored.

\section{GOVERNMENT ACCORDING TO LAW}

Roncarelli v. Duplessis ${ }^{6}$ is possibly the most famous of all decisions of the Supreme Court of Canada in the century of its existence. It is the first case in a collection of administrative law decisions now or recently used by students in a New Zealand university. It is also one of the few Canadian decisions

4 The second is the appellate tribunal in matters of education, designated by s. $93(4)$ of The British North America Act, 1867, and consisting of the Governor General in Council. The memoranda printed by way of preface to the Supreme Court Reports for 1974 show the Chief Justice to have been sworn of "Her Majesty's Privy Council", which I take to be the Queen's Privy Council for Canada, on 7th January, 1974. For the third court, see post, and n. 127.

- The seven subjects classified under "Substantive Law" were security of the person; of property; of marriage; of public worship; of thought, speech, and character; of contract and business; of foreigners. The three under "Administrative Law" were The Judicature; The Legislature; and The Executive Government (including local self-government).

6 [1959] S.C.R. 121. 
cited, for example, in Professor H. W. R. Wade's Administrative Law. It is famous for many reasons. For one thing it was a damage action against a Prime Minister in office, though in this it is not unique. There have since been two others in Canada, of which I shall wish to say something in due course - Jones v. Bennett ${ }^{8}$ and Roman Corporation Ltd. v. Hudson's Bay Oil and Gas Co. Ltd., ${ }^{9}$ against Premier W. A. C. Bennett of British Columbia and Prime Minister Pierre-Elliott Trudeau, respectively. Roncarelli's Case was also a successful damage action (as was Jones v. Bennett). That, in the political climate of the time in Quebec, was a matter of no small importance. A personage enjoying something close to absolute political power in the province was humbled by the courts. I myself believe that only Quebec's position as part of a federal state kept it from becoming to all intents and purposes a Latin-American-type dictatorship - setting limits both legal and extralegal as to the behaviour which could or would be tolerated. As it was, the corruption even of the electoral process by money and violence was notorious, and, in the absence of external constraints, would, I think, have attained proportions which would have made impossible (as it certainly made very difficult) peaceful change of power at the polls. In any event, Roncarellis Case provided, as my teacher and colleague Dean Frank Scott likes to say, a footnote for Dicey's proposition, - which is indeed quoted by Mr. Justice Abbott ${ }^{10}$ - that "every official, from the Prime Minister down to a constable or a collector of taxes, is under the same legal responsibility for every act done without legal justification as any other citizen. The Reports abound with cases in which officials have been brought before the courts, and made, in their personal capacity, liable to punishment, or to the payment of damages, for acts done in their official character but in excess of their lawful authority."11

It is a case to which one must turn again and again. The power of the state; the definition, attribution, and limitation of public authority; the location and scope of responsibility for acts done in virtue of, or under colour of, office, - these are the very stuff of civil liberty, and Roncarelli v. Duplessis raised them in a very striking way.

Its basis in fact was essentially simple, and rested on the allegation that Hon. Maurice Duplessis, then Premier and Attorney-General of the Province of Quebec, had caused M. Edouard Archambault, Manager and sole member of the Quebec Liquor Commission, to cancel the plaintiff's liquor permit for legally improper reasons, so bringing ruin to his restaurant. The case, as Dean Scott says, was won on cross-examination of the Premier by Mr. A. L. Stein, Q.C. (as he now is) of the Montreal Bar. Substantial portions of this cross-examination may be found quoted in the reasons of various judges, especially those of Mr. Justice Rand. I rather fear that many readers, student readers especially, in common-law Canada skip it because it is in French. Here in my translation are two excerpts from the Premier's evidence: ${ }^{12}$

If I had said to Judge Archambault, "Don't do it", he probably wouldn't have done it. As he had suggested to me that it be done and as after reflection and checking I found that it was right, that it was in accordance with my duty, I approved it and that's in any case an order that's being given. When a superior officer is speaking, an order is being given, even if he accepts the suggestion of an officer in his department, an order is being

7 3rd ed. (Oxford, 1971), at 110.

8 [1969] S.C.R. 277.

9 [1937] S.C.R. 820.

${ }^{10}$ Supra, n. 6 at 184.

11 A. V. Dicey, Introduction to the Study of the Law of the Constitution, 10th ed. (London, 1960) at 193.

12 Supra, n. 6 at 136-7. 
given indirectly. I don't remember the exact words used, but those are the facts. . . . Whether I said here [at a press conference] "A certain Mr. Roncarelli has supplied bail for hundreds of witnesses of Jehovah. The sympathy which this man has shown for the Witnesses in such an evident, repeated and audacious manner, is a provocation to public order to the administration of justice and is definitely contrary to the aims of justice." I said it, and I consider that it's true.

and one from that of M. Archambault: ${ }^{13}$

Certainly, that day I had called the Prime Minister, on that occasion the AttorneyGeneral, bringing to his attention the things I had ascertained, that is to say the information I had, and my intention to cancel the privilege, and the Prime Minister answered telling me to be careful, to make sure that the same person was involved, that there could be many Roncarellis, and so on. Then, when I had confirmation from Y3 [a private investigator] that it was the same person, I phoned the Prime Minister to assure him that it was definitely Frank Roncarelli, who held a permit from the Liquor Commission; and then the Prime Minister authorized me, he gave me his consent, his approval, his permission, and his order to go ahead.

\section{A. Power in Fact}

To suppose that this by itself settles, as a matter of law, the question of causality is, I submit, a mistake. The issue is one of much difficulty and delicacy. For if the defendant caused, as he was held to have caused, the revocation of the plaintiff's permit, this was not through any conventional sort of coercion, or threat of coercion, directed against the manager. Nor did the defendant mislead the manager as to the facts. (In what circumstances liability could flow from a misleading, even a wilful misleading, as to the law, is not free from difficulty.) Mr. Justice Rand appears to have expressed at least the majority view of the causal nexus when he spoke of "the de facto power of the Executive over its appointees at will". ${ }^{14}$ In other words, a threat of dismissal for disobedience was implicit in the Premier's order, however eager (it seems) the manager in fact was to comply. Yet the power to dismiss did not in law rest with the Premier. It rested with His Honour the Lieutenant-Governor in Council. ${ }^{15}$ In strictness of law the Lieutenant-Governor would not have had the slightest obligation to accede to the advice of the Premier, or of the whole Executive Council, to dismiss the manager. The accepted constitutional practice is, no doubt, to accede to advice, but this accepted practice rests purely on convention. That is to say, it is wholly extralegal. In a sense, it can be said to be a matter of fact rather than a matter of law. Assuming that this practice is properly noticeable judicially, - I have not read the record in Roncarellis Case but should be surprised to find that evidence was adduced to establish it, - it is a matter worthy of remark that the court held, or at least assumed, that the measure of the Premier's power in fact could be taken in order to establish a necessary ingredient of his liability in law. That I put into question the legitimacy of such considerations may affront some who will think it to savour of quibble, especially given the facts of that case. But many situations will seem less clear-cut. While it may be necessary, it will not be easy, to define or to manage a doctrine under which the civil liability of a man who has intimated his wishes to an organ of government, for the consequences of its acts, is predicated even in part upon an assessment of his influence.

\section{B. Jurisdiction, Discretion, and Parliamentary Supremacy}

A second theme in Roncarelli's Case is that of jurisdiction and the scope of discretion. Sooner or later most, perhaps all, constitutional and administrative law problems turn on a question of jurisdiction. It is, in my opinion,

13 Id.

14 Id. at 137.

15 Alcoholic Liquor Act, R.S.Q. 1941, c. 255, s. 5; Interpretation Act, R.S.Q. 1941, c. 1 , s. 55 . 
inevitable that they do so. This seems to me implicit in the first principles of the constitution: in the separation of powers, and, more particularly, in the supremacy of the legislature. If a competent legislature has, in truth, on the true construction of its enactment, authorized person $A$ to do thing $X$, or things falling within class $\mathrm{Y}$, then $\mathrm{A}$ is entitled to do $\mathrm{X}$ or $\mathrm{Y}$. A court which denies $A$ the liberty to do those things, by imposing upon him civil or penal sanctions, is necessarily, however it couches its decision, taking one of three courses. It is denying the competence of the legislature. Or it is denying that the enactment, on its true construction, really authorizes the doing by the person in question of the thing in question with complete impunity. Or it is simply disobeying the law; wilfully refusing to apply it. The decisive question will, therefore, be: What did the legislature authorize $A$ to do and on what conditions (if any)? And (it may be): What did the law empower the legislature to authorize? These are jurisdictional questions. Within his jurisdiction, A may freely wander. From the Latin, we have the synonym "err". A may err within his jurisdiction. That in doing so he may be in breach of some commonlaw rule or even legislative direction is in principle irrelevant to his impunity and to the validity of his acts, so long as those common-law or statutory rules do not define his jurisdiction. And where the legislature is competent, the limits of his jurisdiction can never be more than a question of construction. There is, in short, no general judicial right to review the merits of the exercise of power conferred by statute exactly because there is no appeal from the acts of the legislature itself. (I suppose that I should say, parenthetically, that I consider the availability of certiorari to correct an error of law on the face of the record to be at most a modest exception to the general principle. The superior courts have assumed to consider as their own flesh and blood, like unto themselves and so suitable for their own special revision and control, bodies which, though not necessarily designated courts by name, are found, on the true construction of some enactment, to be bound to exercise a given power in a "judicial" manner, even if the "judicial" process in question is shorn of many of the incidents which normally attend the exercise of judicial power.)

Now in Roncarelli's Case the critical words of the Alcoholic Liquor Act ${ }^{16}$ were those of the first subsection of section 34: "The Commission may refuse to grant any permit." and the first subsection of section 35:

Whatever be the date of issue of any permit granted by the Commission, such permit shall expire on the 30th of April following, unless it be cancelled by the Commission before such date, or unless the date at which it must expire be prior to the 30th of April following.

The Commission may cancell [sic] any permit at its discretion.

After setting out the relevant provisions of the Act at length, Mr. Justice Cartwright (as he then was) came to this conclusion: ${ }^{17}$

On a consideration of these sections and of the remainder of the Act I am unable to find that the Legislature has, either expressly or by necessary implication, laid down any rules to guide the commission as to the circumstances under which it may refuse to grant a permit or may cancel a permit already granted. In my opinion the intention of the legislature, to be gathered from the whole Act, was to enumerate (i) certain cases in which the granting of a permit is forbidden, and (ii) certain cases in which the cancellation of a permit is mandatory, and, in all other cases to commit the decision as to whether a permit should be granted, refused, or cancelled to the unfettered discretion of the commission.

16 Id.

17 Supra, n. 6 at 166-7. 
It is necessary to add that his Lordship also went on to hold that the order cancelling the permit was administrative, and not quasi-judicial, in nature, so that, in his view, Roncarelli was not entitled to a hearing, with the result that the failure to give him a hearing before cancelling his permit did not vitiate that order. Important as this distinct ground of attack may have been to Roncarelli on the facts of his particular case, - against the possibility that his other grounds might fail (as in Mr. Justice Cartwright's view they did), and important as the right to a hearing may in general be, the issue was in the event dwarfed by the question as to the purposes for which the Commission's power could competently be employed. Clearly the formality of a hearing would be cold comfort to others in Roncarelli's position. Mr. Justice Cartwright summed up the results of his analysis: ${ }^{18}$

For the above reasons I have reached the conclusion that the heavy financial loss undoubtedly suffered by the appellant was damnum sine injuria. The whole loss flowed directly from the cancellation of the permit which was an act of the commission authorized by law.

What answer can be made to this dissent of Mr. Justice Cartwright? Is his Lordship not applying the statute to the letter? Does the legislation not in truth provide a complete defence to such a claim as that of Roncarelli? It is not enough to dismiss the objection airily. A strong case can be made for his Lordship's position.

A statute is not a theme upon which courts of law are invited to spin variations. Nor is it a suggestion offered to them for whatever they may think it worth. A statute is a peremptory exercise of absolute and arbitrary power. Its authority flows not from the statute's merits or presumed merits, but from the mere fact of its enactment by the persons and in the manner and form laid down by the existing law respecting the method of lawmaking. To refuse to apply the statute is to confront the process which has presumed and purported to make law and to put in question its authority. If that authority is established, there is, under the rule of law, no room for anything short of absolute submission to what is, by hypothesis, lawful authority.

If, therefore, disclaiming or repelling any challenge to the validity of the enactment, a court proceeds to construction, it is immediately faced with questions of high constitutional principle as to the methods appropriate to statutory interpretation. The basic rule is, and must be, that words mean what they say. That is not because such a starting point seems as convenient as any other, nor because the judges happen to find it congenial. Rather it is because the lawmaking authority, through the use of plain and unmistakable words, has clearly dictated its will, and because the expression of that will, once its meaning has been ascertained, is, as a matter of first constitutional principle, final and absolute. "It shall be lawful for the Queen, by and with the Advice and Consent of the Senate and House of Commons, to make Laws for the Peace, Order and good Government of Canada ...", begins section 91 of the Act of 1867. "In each Province the Legislature may exclusively make Laws . . .", continues section 92. This is plain English, and its meaning in the present context does not seem to me to admit of any doubt. It is the legislature, and not the court, which is to make the statute. "In assigning legislative power to the one or the other of these parliaments, it is not made a statutory condition that the exercise of such power shall be, in the opinion of a court of law, discreet. In so far as they possess legislative jurisdiction, the discretion committed to the parliaments, whether of the Dominion or of the provinces, is unfettered. It is the proper function of a court of law to determine what 
are the limits of the jurisdiction committed to them; but, when that point has been settled, courts of law have no right whatever to inquire whether their jurisdiction has been exercised wisely or not." The words are those of Lord Watson speaking for the Judicial Committee in Union Colliery v. Bryden. ${ }^{19}$ The starting point for the construction of statutes is, and I say flatly, constitutionally must be, the literal meaning of the enactment. Any departure from this principle raises grave constitutional questions precisely because an admittedly competent lawmaking authority then seems to have said one thing whilst the courts are saying another and appearing to rebel against lawful authority. Very cogent reasons indeed must therefore be offered to show why the legislature is to be taken as having meant something other than what, literally, it has said.

In the context of Roncarellis Case, it was Mr. Justice Rand who offered the necessary cogent reasons in a very memorable passage of the first importance: ${ }^{20}$

The field of licensed occupations and businesses of this nature is steadily becoming of greater concern to citizens generally. It is a matter of vital importance that a public administration that can refuse to allow a person to enter or continue a calling which, in the absence of regulation, would be free and legitimate, should be conducted with complete impartiality and integrity; and that the grounds for refusing or cancelling a permit should unquestionably be such and such only as are incompatible with the purposes envisaged by the statute: the duty of a Commission is to serve those purposes and those only. A decision to deny or cancel such a privilege lies within the "discretion" of the Commission; but that means that decision is to be based upon a weighing of considerations pertinent to the object of the administration.

In public regulation of this sort there is no such thing as absolute and untrammelled "discretion", that is that action can be taken on any ground or for any reason that can be suggested to the mind of the administrator; no legislative Act can, without express language, be taken to contemplate an unlimited arbitrary power exercisable for any purpose, however capricious or irrelevant, regardless of the nature or purpose of the statute. Fraud and corruption in the Commission may not be mentioned in such statutes but they are always implied as exceptions. "Discretion" necessarily implies good faith in discharging public duty; there is always a perspective within which a statute is intended to operate; and any clear departure from its lines or objects is just as objectionable as fraud or corruption. Could an applicant be refused a permit because he had been born in another province, or because of the colour of his hair? The ordinary language of the legislature cannot be so distorted.

To deny or revoke a permit because a citizen exercises an unchallengeable right totally irrelevant to the sale of liquor in a restaurant is equally beyond the scope of the discretion conferred. There was here not only revocation of the existing permit but a declaration of a future, definite disqualification of the appellant to obtain one: it was to be "forever". This purports to divest his citizenship status of its incident of membership in the class of those of the public to whom such a privilege could be extended. Under the statutory language here, that is not competent to the Commission and $a$ fortioni to the government or the respondent ....

Mr. Justice Rand, it may be observed, does not deny that the legislature can invest in an administrator an unlimited arbitrary power exercisable for any purpose. His Lordship simply says that the legislature cannot be held to have done so in the absence of express language. His plea is one of confession of legislative sovereignty, and avoidance.

How can such a mode of construction be reconciled with the supremacy of a competent legislature - with government according to law?

A statute is a formal jural act. The law must necessarily define the conditions of its existence. It can also require that certain formalities of whatever kind must be compiled with if the jural act is to produce certain results or operate in a certain way. The lawmaking process is defined in part by statutory rules

19 [1899] A.C. 580 at 585.

20 Supra, n. 6 at $140-141$. 
of various kinds, and in part by rules of the common law. There is nothing anomalous in a rule requiring that express words, or specially clear and unmistakable language, must be employed to accomplish certain legal results. Such rules are to be found on the statute books, notably in Interpretation Acts, ${ }^{21}$ and, I submit, in the Canadian Bill of Rights. ${ }^{22}$ The common law, too, has such rules, of varying strength. Some of these rules can properly be seen as imposing implied conditions upon statutory language. Others are probably better understood as common law rules of independent operation which will not be held excluded or overridden by statute in the absence of sufficiently clear words.

These rules are all of great importance to the liberty of the subject. They have been laid down, and made to operate by way of exception to the literal interpretation of statutes, because without them the legislature could too easily, too casually, too unthinkingly, work great injustice. They are familiar rules but I must digress with regard to some of them.

\section{(i) Natural Justice}

Amongst them is the rule which gives to a person whose rights are affected by the exercise of powers of a judical nature (whether or not vested in bodies called "courts") the right to "natural justice", that is, to a hearing and a determination free from bias. In general, I think that the Supreme Court of Canada has adopted a balanced approach to the scope of this right. It is no more possible, in my view, to imply a right to a hearing on the part of everyone affected by every executive act than it is in respect of legislation. The consequence is that executive or administrative acts must necessarily include a class as to which there is no analogy with the judicial function - no "duty to act judicially". These must exist both at common law and by statute. Whether they are called executive or "purely administrative" to distinguish them from those others which are at once "administrative" and "quasi-judicial" does not greatly matter. The point is that the distinction is not, in my opinion, and can never become, obsolete. That leaves the main problem - which is, of course, characterisation. I would do no more here than refer to a few of the landmarks of the Supreme Court's jurisprudence: Toronto Newspaper Guild v. Globe Printing Company ${ }^{23}$ and Alliance des Professeurs Catholiques v. Labour Relations Board of Quebec, ${ }^{24}$ both decided in 1953, and insisting on a substantial hearing in labour relations matters; Guay v. Lafleur ${ }^{25}$ (1964), denying a right to representation in an inquiry which involved simply the decision whether to institute proceedings against a person; The Queen v. Randolph $^{28}$ (1966), denying a right to a hearing on an interim order suspend-

21 For example, s. 16 of the Interpretation Act, R.S.C. 1970, c. I-23, which provides that "No enactment is binding on Her Majesty or affects Her Majesty's or Her Majesty's rights and prerogatives in any manner, except only as therein mentioned or referred to." The version in the Interpretation Act, R.S.C. 1906, c. 1, s. 20, reads: "No provision or enactment in any act shall affect, in any manner whatsoever, the rights of His Majesty, his heirs or successors, unless it is expressly stated therein that His Majesty shall be bound thereby." To the contention that this could be excluded by the "irresistible implication" of a later statute, Viscount Dunedin responded: "The simple answer to this is to fix one's eyes on s. 16, and it becomes apparent that it is a contradiction in terms to hold that an express statement can be found in an "irresistible implication" (In re Silver Brothers, Limited [1932] A.C. 514 at 523).

22 Part I of An Act for the Recognition and Protection of Human Rights and Fundamental Freedoms, 8-9 Eliz. II, S.C. 1960, c. 44, as amended.

23 [1953] 2 S.C.R. 18.

24 [1953] 2 S.C.R. 140.

25 [1965] S.C.R. 12.

26 [1966] S.C.R. 260. 
ing postal service, where the statute specified a hearing before the order could become final. The decision which gives me much difficulty is Calgary Power v. Copithorne ${ }^{27}$ (1959), where a hearing was denied on a ministerial order of expropriation. I wonder whether it would have been decided the same way had Ridge v. Baldwin ${ }^{28}$ (1964) come first from the House of Lords.

\section{(ii) Prerogative Remedies}

Then there is the rule that "prerogative remedies", available in the superior courts to review the acts of inferior administrative and judicial authorities, cannot be excluded without clear language, and that even where clear words are present ousting these remedies the "privative clause" will not protect excess of jurisdiction. Of this I shall wish to say something in due course. ${ }^{29}$

(iii) Criminal Responsibility

There is also the rule requiring, in general, mens rea, - literally, the guilty mind, - as a condition of criminal responsibility. Even if the statute is silent on the matter, and defines the crime as arising from a given set of facts, without in terms requiring that these facts must exist to the knowledge of the defendant, or that he be reckless as to their existence, this will in principle be implied by the common law. Lord Kenyon thought it "monstrous"30 not to do so. The rule finds its leading reaffirmation in Canada in Beaver v. The Queen, ${ }^{31}$ a 1957 Supreme Court decision, exculpating from the crime of possessing narcotic drugs a person in physical possession of a package containing a narcotic drug, but which he believed to contain a harmless substance. The majority was a narrow one, made up of Rand, Locke, and Cartwright, JJ. Fauteux and Abbott JJ. dissented. Mr. Justice Cartwright pointed out ${ }^{32}$ that the matter was not one of burden of proof or of the obligation of adducing evidence, for, without the requirement of mens rea the accused "must be convicted even if he proves to the point of demonstration that he honestly believed the package to contain a harmless substance such as baking-soda. ..." Such a result would plainly be grotesque, and it is not easy to see how the social purpose of suppressing narcotic drugs would be insufficiently served by adjusting the burden of proof, or of adducing evidence, to the necessities of the case. I myself thought as a law student that the implications of his position could have been brought home to Mr. Justice Fauteux, as he then was, by concealing a package of sugar in his robes and then confronting him with the fact of his possession. I rather regret never having had the chance to ask him what punishment he should suffer if the sugar had been a narcotic drug. His Lordship insisted that on "the plain, literal and grammatical meaning of the words" of the section, there was "an absolute prohibition to be in possession of drugs".83 As few provisions creating offences expressly require knowledge or intent, unless to require a special intention, it is hard to see what room would be left for mens rea. In 1967 the Queen's Bench Division of the English High Court convicted one Stephanie Sweet of an offence of being concerned in the management of premises used for the purpose of smoking cannabis, she being ignorant of the fact that one or more of her tenants had smoked cannabis in a

27 [1959] S.C.R. 24.

28 [1964] A.C. 40.

20 Below, p. 126 ff.

30 Fowler v. Padget (1798) 7 T.R. 509; 101 E.R. 1103.

s1 [1957] S.C.R. 531 .

32 Id. at 536.

${ }^{83} \mathrm{Id}$. at 549. 
farmhouse in which she let rooms. The House of Lords ${ }^{34}$ allowed the appeal, the late Lord Reid describing the result as "obviously unjust", finding it "firmly established by a host of authorities that mens rea is an ingredient of every offence unless some reason can be found for holding that it is not necessary", ${ }^{35}$ and warning that "every manifestly unjust conviction made known to the public tends to injure the body politic by undermining public confidence in the justice of the law and of its administration." ${ }^{.38}$ Of a full bench of nine, a majority of eight judges of the Supreme Court of Canada in 1970 in The Queen v. Pierce Fisheries Ltd. ${ }^{37}$ held possession of lobsters of a length less than that specified in the Lobster Fishery Regulations to be a "strict liability" offence, for which no mens rea was required. Mr. Justice Ritchie, writing the reasons of the majority, thought that the offence was not a "truly criminal offence", ${ }^{38}$ carried no comparable stigma, and, having regard to its subjectmatter and the language of the regulations, was one of the "wide category of offences created by statutes enacted for the regulation of individual conduct in the interests of health, convenience, safety and the general welfare of the public which are not subject to any such presumption." ${ }^{39}$ This particular language, though it is sanctioned by many years of judicial usage, seems unfortunate, in that it does not really help to distinguish minor offences from the gravest crimes, which can all $a$ fortiori be described in exactly the same terms. When, then, can the requirement of mens rea justly be excluded? I hazard this tentative guess. First, strict liability in criminal law can be a method of encouraging compliance by simply depriving the offender of the benefits, exactly or roughly estimated, of violation, however innocent. That does not shock the conscience. Second, criminal process may also be coercive in imposing a continuing sanction even against innocent default, but ending with compliance. In these cases the criminal remedy will closely resemble the civil, and may properly be assimilated for certain purposes, ${ }^{40}$ including exclusion of the requirement of mens rea. The line may be hard to draw and the same facts may give rise to both civil and criminal remedies. Consider the contumacious character of the defiance of a court order to refrain from watching or besetting a ship or interfering with access or loading - a very timely problem, I suggest. Kellock, J., speaking for three of five judges in a unanimous Supreme Court bench in Poje v. A.-G. British Columbia ${ }^{41}$ wrote: ${ }^{42}$

The Court of Chancery has for centuries enforced its orders by contempt proceedings, but it is well settled that such orders, when merely made in aid of execution of process for the benefit of a party, are to be regarded as purely civil in nature. It is equally well settled that conduct which renders appropriate contempt proceedings in aid of execution may have a criminal aspect as well. . . .

It is idle to suggest that on the evidence the presence of these large numbers of men blocking the entrance to the bridge was intended merely for the purpose of communicating information. That had been very efficiently done for a considerable time by the six pickets with their signs or cards, and the notices at the bridgehead. The congregation of the large numbers of men at the time that the longshoremen were to arrive had no other object or effect than to present force.

34 Sweet v. Parsley [1970] A.C. 132.

35 Id. at 148-9.

${ }^{30} \mathrm{Id}$. at 150 . There is a fine passage in the speech of Lord Pearce, at 157, from A down to $D$.

87 [1971] S.C.R. 5.

$38 \mathrm{Id}$. at 19.

${ }^{80} \mathrm{Id}$. at 13.

10 See, e.g., Stourton v. Stourton [1963] P. 302.

41 [1953] I S.C.R. 516.

$\$ 2 I d$. at 517 and 526-7. 
The context in which these incidents occurred, the large numbers of men involved and the public nature of the defiance of the order of the court transfer the conduct here in question from the realm of a mere civil contempt, such as an ordinary breach of injunction with respect to private rights in a patent or trade-mark, for example, into the realm of a public depreciation of the authority of the court tending to bring the administration of justice into scorn.

Contempt proceedings could accordingly be carried on with or without the consent of the victim, and the rights of appeal were those in criminal matters. Third, strict liability offences are most commonly found by judicial construction in statutes aimed at carelessness rather than, or equally with, wilful breach. Such are enactments against giving short weight, for example, or selling unwholesome food. The difficulty is that a rule of strict liability punishes even a defendant who has taken every precaution, and indeed one in default through the malicious act of a third person. Where the sanctions are relatively light and the stigma not significant, the injustice may be tolerable, particularly if the defendant is in roughly the same position as if he had been in default of a civil obligation based upon the assumption of risk, and so can plausibly be understood as repairing his breach of a quasi-civil obligation to the public at large. Where, however, the penalties are graver, the injustice can become manifest, so that a statute with serious penalties aimed at enforcing care and attention should be so drafted as to admit the defence that the defendant took all reasonable measures; the proof, if need be, being made to lie with him. It is interesting to observe from $\mathrm{Mr}$. Justice Ritchie's reasons ${ }^{43}$ in the lobster case, that Pierce Fisheries Ltd. would probably have failed to make good such a defence. The result in their case was to punish their failure to take precautions. How far the courts could now properly adopt a rule of construction along the lines just stated (excusing defendants who have taken all reasonable measures) as a media via between ordinary standards of criminal responsibility and strict liability it is hard to say. Chief Justice Cartwright concluded his dissent in the Pierce Fisheries Case with the question" "whether it would not indeed be in the public interest that whenever it is intended to create an offence of absolute liability the enacting provision should declare that intention in specific and unequivocal words."

\section{(iv) Implied Condition of Reasonableness}

Another attempt to reconcile the sovereignty of the legislature with the urgent needs of justice lies in a doctrine of doubtful basis and uncertain scope. That is the doctrine that there may be implied into statutory powers a condition that they must be exercised reasonably.

This doctrine is best established as regards the construction of municipal powers of making by-laws. I would hazard the guess that, in its modern form, it is purely accidental. So long as municipal authorities were created by royal prerogative, it would have been anomalous, and indeed dangerous, to allow the Crown, itself unable to legislate save in Parliament, to put unfettered legislative power into the hands of bodies whose constitutions it could define, and which might be narrow oligarchies or even instruments of the Crown itself. It was therefore necessary to imply as a common-law condition that by-laws must be reasonable. But when municipal powers became statutory no consid-

13 Supra, n. 37 at 21: "As employees of the company working in the premises in the shed "where fish is weighed and packed" were taking lobsters from boxes "preparatory for packing" in crates, and as some of the undersized lobsters were found "in crates ready for shipment", it would not appear to have been a difficult matter for some "officer or responsible employee" to acquire knowledge of their presence on the premises.'

4 Id. at 12. 
eration seems to have been given to the legal justification of the condition of reasonableness, and it became engrafted onto statutory powers. Of course one can find distinguished statements of the scope of this condition, and its nature as part of the doctrine of ultra vires. ${ }^{45}$ Yet how can one justify such a condition on some statutory powers but not others? Why municipalities and not Ministers, or governors in council? How can one avoid coming to the conclusion that it must be all or none? Is there not a hint of the latter choice, for example, in the remark of Viscount Radcliffe, ${ }^{46}$ concerning the powers of a local authority, that if the "power can be seen from the wording of the Act to be subject to some limitations, despite the very ample words of conferment, it is the duty of the court to enforce those limitations .... But, further than that, I do not think the court can go"? By contrast, some English decisions have suggested that there may be a generalized condition of "fairness" upon the exercise at any rate of administrative powers, even when not judicial in nature. ${ }^{47}$ Clearly the Supreme Court of Canada can be expected, in the years ahead, to be confronted with choices of momentous importance, and of great difficulty.

For in the sixteen and one-half years since the decision in Roncarelli's Case statutory powers of enormous scope have been conferred upon public authorities throughout Canada, with vast implications for the liberty of the subject. Some concern has been shown in the more enlightened quarters of this country; concern reflected in the McRuer Report ${ }^{48}$ and the McGuigan Report ${ }^{40}$ and in attempts to implement them to secure adequate control. Abuses are nevertheless bound to occur everywhere, and in some places the Legislature invites them. Consider, for example, legislative practice in Quebec, as reflected in one or two recent Acts and bills.

The Cultural Property Act ${ }^{50}$ of Quebec gives the Minister, with the advice of a Commission whose members are appointed for fixed terms not exceeding three years, to "recognize" or "classify" "cultural property". Recognition entails prohibition of the export from Quebec of cultural property; prohibition to "destroy, alter, restore, repair or change in any manner recognized cultural property"; prohibition to alienate without notice to the Minister; a right of pre-emption by the Minister if the property offered for sale is fifty years old; a duty to notify the Minister within thirty days of possession of recognized cultural property acquired through legal and testamentary succession; a power to expropriate. Alienations contrary to the Act are null, and contraventions of the Act are punishable by a five thousand dollar fine without prejudice to other recourses.

Now some may think, and I am prepared to be persuaded, that where the property involved is truly of public significance, such powers are justified. For my part I would submit that the owner ought at least to have the right to require the Minister, if he wishes to control it, to buy it outright at full market value: a public which wants museums and museum pieces should be prepared to

${ }^{45}$ See, e.g., Kruse v. Johnson [1898] 2 Q.B. 91, per Lord Russell, C. J., at 99-100. See recently also Diplock, L. J. in Mixnam's Properties Ltd. v. Chertsey U.D.C. [1964] 1 Q.B. at 237-8.

46 On appeal in the Mixnam's Properties Case [1965] A.C. 735 at 735D.

${ }^{47}$ In re H. K. [1967] 2 Q.B. 617; Reg. v. Gaming Board for Great Britain ex. p. Benaim [1970] 2 Q.B. 417.

18 Royal Commission, Inquiry into Civil Rights, 1st and 2nd Reports (1968, 1969), (Queen's Printer for Ontario, 1968 and 1969), 4 vols.

19 Canada, House of Commons, Third Report of the Special Committee on Statutory Instruments, Session 1968-69, Mark MacGuigan, Chairman (Ottawa, 1969).

${ }^{50}$ S.Q. 1872 , c. 19. 
pay the cost. But consider just what property it is that is subject to the Minister's power of "recognition". This extends to all "cultural property". The sting lies in the definitions. Cultural property is defined as "a work of art, an historic property, an historic monument or site, or an archaeological property or site". These terms are in turn widely defined. A "work of art" is "a moveable or immoveable property whose conservation is from an aesthetic point of view in the public interest". That includes most good paintings, sculptures, silverware, china, furniture. Then "historic property" is defined to mean "any manuscript, printed item, audio-visual document or man-made object whose conservation is of historic interest, excluding an immoveable". Any reasonable collection of books or manuscripts will contain at least some items of this description, whilst others, old or new, may be "works of art". The definitions do not end here, but I think I have quoted enough for my purpose.

Does this Act, applied to the letter, not confer an arbitrary power to take or control virtually every chattel (I am putting aside immoveables) of cultural interest even transiently in the province? What limits are there to ensure that the public interest is balanced against that of the owner, or even that there is any genuine public interest at all? What safeguards against the Minister's whim? None are expressed; none exist save by implication of law; unless it be the Minister's committee; and are they to deny that the conservation of a good painting "is from an aesthetic point of view in the public interest", simply because of the harsh consequences? What of freedom of movement within Canada?

I turn now to Bill No. 1 of the current session (Third Session, Thirtieth Legislature, 1975), An Act Respecting the Cinema, as it stands today in the Quebec Legislature at first reading. It begins with a recital that "the cinema is among the most powerful means for cultural expression and propagation" and that "it is fitting that Quebec assert its sovereignty in this field". This it may be remarked, suggests less pre-occupation with good government than appetite for the exercise of power. The implications of preamble and provisions alike cannot be assessed otherwise than in the light of their potential extension to other media - books, newspapers, and indeed telecommunications, should the latter ever suffer the misfortune of falling under provincial control. In quoting some of the provisions of this Bill - rather more than I should wish - I would stress that the "director" in question is the director of the proposed film-classification service, who will be a civil servant expressly put under direct ministerial "authority", replacing a Board which, at any rate in practice, acts, as I understand it, as an independent agency. ${ }^{51}$ The "Committee" is a committee of five

51 Clause 12 of the Bill provides that the director "shall be appointed and remunerated in accordance with the Civil Service Act". The Civil Service Act, S.Q. 1965, c. 14, as amended, would, if I read it correctly, by s. 33 place the appointment in the hands of the Minister (i.e., here, the Minister of Cultural Affairs), and require (by s. 61) the recommendation of the Civil Service Commission as a condition of dismissal, with a right to a hearing and transmittal of the record to the Lieutenant-Governor in Council. By s. 55 of the Interpretation Act, R.S.Q. 1964, c. 1, power of appointment carries with it power of removal. Various clauses of the Bill refer to the acts of the director as being "under the authority of the Minister", which seems to imply ministerial control. Moreover, the "film classification service" consisting of the director and "personnel deemed necessary" is said to be established "at the Department of Cultural Affairs". The present Cinema Act, R.S.Q. 1964, c. 55, as amended, places "supervision", including censorship, of the cinema in the hands of a "Cinema Supervisory Board" - without any fixed term - appointed by the Lieutenant-Governor in Council, and therefore, under the Interpretation Act (supra) removable by him. In practice it appears that this Board has operated independently of the government. The regulatory powers of the Lieutenant-Governor in Council are negligible by comparison with those proposed in the Bill. 
members, three appointed by the Minister (and removable by him), ,2 and two appointed and removable by an Institut Québécois du Cinéma, itself created by the Act and composed of ten appointees of the Lieutenant-Governor in Council holding office for three-year terms. The "minister" is the Minister of Cultural Affairs - a portfolio held at present by M. Denis Hardy, who introduced the present Bill. The "regulations" are those to be made by the LieutenantGovernor in Council. The Bill provides:

8. The Lieutenant-Governor in Council, if he considers that suitable market outlets for Québec films are unduly restricted in Québec, may, by regulation, require the owners and operations of moving picture theatres to include Québec films in their programming, in such proportion as he indicates.

That proportion may vary depending on the region or locality, the audience, and the class of films or moving picture theatres concerned.

11. The Minister may take action against any practice employed in film distribution and exhibiting in Québec if he considers that such practice tends to thwart the cultural needs of the population by depriving them of films of good quality or by unduly delaying the exhibiting of such films.

In exercising such power, the Minister may prohibit any restrictive practice, nullify any transaction involving the ownership of a firm whose activities relate to the cinema, and obtain the appropriate injunctions from the Superior Court or judges of such court.

15. The director shall also be entrusted with classifying, under the authority of the Minister, the cinematographic films which it is proposed to exhibit in Québec, to approve the advertising connected with the exhibiting of such films and to perform every other duty which devolves to him by this act or the regulations.

16. It is the duty of the director to examine any cinematographic film which it is proposed to exhibit in Québec and to authorize it for exhibition if, in his opinion, the exhibiting of it is not prejudical to public order or morality.

The director may require any information he considers necessary from persons requesting him to classify a film.

21. A committee is established to review the decisions of the director regarding film classification. The committee shall consist of three members appointed by the Minister and two members appointed by the Institut. . . .

22. Every person who, having submitted a film to the director for classification, is dissatisfied with the decision rendered, may appeal therefrom to the committee of review within fifteen days from the date of the decision.

The committee may confirm, quash or amend the decision of the director.

The committee's decision is final.

23. It is forbidden to lease, lend, forward for exhibition in a moving picture theatre in Québec or to exhibit in such a theatre, any film that has not been classified in conformity with this chapter, or to alter a film in any manner not authorized by the director.

Any advertising connected with a film not in conformity with the advertising approved by the director on classifying the film is prohibited.

26. Any person authorized by the Minister and bearing a search warrant may enter any place where films intended for exhibition in moving picture theatres are kept; he may examine them to ascertain whether they have been classified and whether they have been authorized for exhibition in conformity with this chapter.

Such person must confiscate every film not in conformity with this act or the regulations.

Search warrants shall be issued in accordance with the Summary Convictions Act.

27. The regulations may prescribe that films of the classes indicated therein must, if the original version is not in French, be accompanied with a version with French dubbing or subtitles, without which they cannot be submitted for classification.

Dubbing and the addition of subtitles must be done entirely in Québec, subject to any exception provided by regulation or any agreement between the Minister and another government.

Apart from the spirit of mean and petty dirigisme which informs the whole Bill; apart from the vicious and bigoted parochialism of clause 27; I think it

B2 Interpretation Act, R.S.Q. 1964, c. 1, s. 55. 
clear that this Bill, which establishes a virtual dictatorship over a major medium of expression, can have no place in a free society. The Cultural Property Act, too, I submit, also grossly exceeds anything that circumstances can reasonably require.

I have selected only a few egregious examples, - omitting, for example, those to do with language and education, - from the dozens available in Quebec and elsewhere. The powers, though not in law his, which enabled Maurice Duplessis to destroy Frank Roncarelli, - for despite Roncarelli's success in the Supreme Court thirteen years after the fact he was ruined (I am told) - have since been multiplied a hundred-fold. It is no longer merely a question of liquor licensing. Every walk of life has become subject to pervasive discretionary controls of every kind; and the safeguards, largely, are only such as the courts of law will imply. The examples I have chosen are clear cases where the draftsmen, - the Minister, - the cabinet, - ultimately, in a purely formal way, the Legislature, - have asked not how narrowly statutes may be drawn to serve reasonable legislative purposes, but how widely. They have sought not the least necessary power for the executive, but the most possible power. At times, as in the Cinema Bill, the result is lunacy. In Quebec, indeed, civil liberty is far more threatened now than it ever was in the times of Duplessis. Do we not know how the power to destroy or damage a man's livelihood is employed in the Soviet Union? Suppose the present government to be Solomons: we need only heed their own warnings to be assured that the Opposition are not: and it is the Opposition who may later exercise the powers the government have put onto the statute books. The powers themselves, when coupled with social unrest, are twice as dangerous.

Now if the powers conferred so largely were to be exercised by men with the wisdom of Solomon and the hearts of angels, despotism of this sort might be acceptable. But the philosopher king lives only in the fatuous dreams of the naive. Drastic measures are unquestionably necessary at times to preserve the fabric of society against major peril from within or without, - to doubt it is equally naive, - and the paradox of constitutional dictatorship has faced every society, from the Greek city-states and republican Rome, through the Weimar Republic, to our own. I will go so far as to hazard the guess that we will be driven back to legislative justice, - acts of attainder and of pains and penalties, - to deal with terrorism and organized crime, which in my opinion present greater potential threats to civil liberty than the actual threats involved in any governmental action yet encountered in Canada. (Anyone who thinks that such legislation is unknown in Canada has not read An Act to Amend the Revised Statutes, 1909, and to provide for the imprisonment of John $\mathrm{H}$. Roberts, being the Act 13 George V, Chapter 18, of the Statutes of Quebec for 1922.) Yet even the exercise of arbitrary power (such as civil conscription of workers and others having no contractual obligation to serve) directly by the legislature is safer than the conferral of vast authority on the executive, which, in practice, usually means the bureaucracy. At times this is doubtless necessary, but there can be no excuse for powers which go beyond the necessities of the case. Candour dictates the acknowledgment that those who in fact come to exercise such powers have neither the wisdom of Solomon nor the hearts of angels. There are in the public service men, - many men, - of talent and dedication. But the corrupt, the incompetent, the bigoted, the arbitrary, the simply stupid, are legion. One need only read in the public press the revelations produced by the recent Quebec inquiries into organized crime and into the construction industry. These vices reach into the highest levels of government; into the legislature itself. And upon such men are conferred virtually the powers of gods. 
(v) Sub-delegation

Implied limitations, then, must loom large if the law is to ensure that even powers insane on their face are to be sanely exercised. I have said something about the implied condition of reasonableness - which the Supreme Court has not yet had to confront starkly - and have spoken of it as one of several departures from the literal application of statutes, required by the common law in the interests of justice and the liberty of the subject. I wish in concluding this enumeration to turn to what may be regarded as the very opposite, an attempt to secure administrative justice by super-literal statutory construction. I am referring to judicial refusal to imply a power to sub-delegate. Like the implied condition of reasonableness, this has hitherto found its special application in municipal matters, for here the Supreme Court of Canada has been almost inflexible. The landmark decisions are of course City of Verdun v. Sun Oil (1951), ${ }^{53}$ City of Outremont v. The (Protestant) School Trustees (1952), ${ }^{54}$ Bridge v. The Queen (1952), ${ }^{55}$ and Vic Restaurant Incorporated v. City of Montreal (1958). ${ }^{\circ 6}$ It is interesting to contrast the opinions of Fauteux, J., for the Court in the first two cases, with his dissent in the last (in which he was joined by Taschereau and Abbott JJ.). The "Vic" in the name of the restaurant, short for Vincent Cotroni, helps to explain the police director's refusal to consent to the issuance of the required permits. The Supreme Court of Canada held that the City's power to fix by by-law the conditions on which permits could be granted did not extend to conferring a discretion as to their issuance. Even where the criteria are laid down in the most explicit terms, the difference between their appearing in a by-law (or other enactment) as conditions of a right to a permit, and appearing as conditions of whose existence some designated person must be satisfied, is enormous. In the one case it is the court which, in the end, decides whether the conditions exist. In the other it is the designated officer. For the Supreme Court to have adopted any other attitude would in my opinion have opened the way to limitless abuse, in place of the more limited abuse possible in administration of controls. Corruption seems to spring up most easily in local government, and there it is the hardest to eradicate. The interests at stake in municipal regulation, especially with regard to land use, are too great to be controlled by any standards of probity which can reasonably be expected at the local level. To many, English standards of public service have always seemed the standards par excellence and beyond reproach. So, by and large, they probably are, - by comparison at any rate to the North American. Yet I have never believed that, in England, given the magnitude of the interests involved in "planning controls", bribery could be anything but widespread, and the revelations of the past few years have shown that corruption there has existed in more than a few isolated cases. I applaud, and encourage, the Supreme Court in its approach. When I spoke of it as almost inflexible, I had in mind mainly $\mathrm{Mr}$. Justice Rand's dissent in part in Bridge's Case. That had to do with the groups of gasoline station operators who would, in rotation, be allowed to remain open after normal hours. He thought that the Council could not, consistently with the accepted principle, commit to an official the discretion as to who should be in each group, and the order of rotation; and I can see no answer to his objection.

\section{Damnum and Injuria}

The law does not impose upon organs or officers of state the obligation to repair all the damage they may cause. What must be repaired is wrongful

\footnotetext{
53 [1952] I S.C.R. 222.

54 [1952] 2 S.C.R. 506.

55 [1953] I S.C.R. 8.

50 [1959] S.C.R. 58.
} 
damage. If compensation for "lawful" damage is wanted, some special legal basis must be shown. In usual cases, it seems, that basis must be statutory. Mr. Justice Cartwright indeed regarded Roncarelli's losses as damnum sine injuria $^{57}$, even on the assumption that the order to cancel the permit was a nullity. Consider the misfortune, at the end of the last century, of one Roy, whose premises were burnt by a fire set along the Canadian Pacific Railway's right of way by sparks or fire escaping from its train. The question, as stated by Lord Halsbury for a Privy Council of seven"8 was "whether the railway company, authorized by statute to carry on their railway undertaking in the place and by the means that they do carry it on, are responsible in damages for injury not caused by negligence, but by the ordinary and normal use of their railway." Their Lordships' answer was: ${ }^{50}$

[T] he ground upon which the immunity of a railway company for injury caused by the normal use of their line is based is that the Legislature, which is supreme, has authorized the particular thing so done in the place and by the means contemplated by the Legislature, and that cannot constitute an actionable wrong in England any more than it can constitute a fault by the Quebec Code. . . .

The Legislature is supreme, and if it has enacted that a thing is lawful, such a thing cannot be a fault or an actionable wrong.

In other words, "No man's life, liberty or property are safe while the Legislature is in session." Here is legislative supremacy with a vengeance. Indeed, here is "paramountcy" with a vengeance. The case was argued by Blake, K. C. for the Railway. That must be Edward Blake, the founder of the Supreme Court whose centenary we celebrate. It is, I think, our pleasant duty this year to honour this giant amongst Canadian jurists and statesmen. Blake put the case as one in which, apart from any other consideration, the federal statute must override the provincial law, whatever that might or might not provide. As their Lordships gave judgment based on the more general defence of statutory authority, whether federal or provincial, the case has escaped the attentions of the constitutional law collectors, and does not figure on the usual academic menus. Nevertheless, - and that is obviously why the Privy Council sat seven, - it illustrates legislative supremacy in general, and federal legislative supremacy in particular, with a vengeance. The acts of the public hangman or of the prison warder, otherwise wanton and outrageous civil (and indeed criminal) wrongs, become by the operation of this rule acts fully justified in law through the statute which confers upon them their authority, and so affords to these officers a complete answer to all proceedings which may be brought against them, whether civil or criminal, federal or provincial. The entire authority of federal statute law depends on the principle in Roy v. C.P.R.

The principle seems to bear with special harshness on Roy because he was in a practical sense expropriated without compensation. Clearly the law cannot make actionable wrongs out of the acts of the legislature itself; and conduct which a competent legislature has in truth authorized it has thereby made its own. Every alteration in the law, every lawful operation of the machinery of the state, is bound to cause damage. What then is the subject's recourse? If he seeks not reparation of wrong, - for by hypothesis no wrong has occurred, - but compensation instead, he is met with the objection that the statute has provided no compensation, and that the common law cannot create such a

${ }^{57}$ Supra, n. 6 at 169.

58 C.P.R. v. Roy [1902] A.C. 220 at 228.

50 Id. at 229 and 231.

${ }^{60}$ M. Frances MacNamara, Two Thousand Famous Legal Quotations (Rochester, N.Y., 1967) p. 393, giving a reference to 1 Tucker (N.Y. Surr.) 249 (1866). 
right, which would in effect impose conditions on the operation of the statute. This, it seems, is so even where property is expropriated outright. The most forceful statement that I can think of is that of Mr. Justice Luxmoore in 1931: ${ }^{61}$

[I]t is a canon of construction that an intention to take away the property of a subject without any right to compensation will not be imputed to the Legislature unless such intention is expressed in unequivocal terms. It is unnecessary to refer to any of the authorities where this has been laid down. It is sufficient to state that this canon of construction is well recognized and has been repeatedly stated and acted upon. Obviously this canon of construction can only be applicable in expropriation cases where there is ambiguity in the actual words to be construed, it cannot apply where there is no ambiguity, for example where there is an expropriation by the act itself and there is complete absence of any words capable of being construed as a right to compensation, and in this connection it seems to me that different considerations apply to a case where there is an actual expropriation as opposed to a power to expropriate . . . .

I am not sure what difference is intended, or can be made, between the case where the Act itself expropriates and the case where the Act authorizes another to do so. Is it meant that the court will refuse to read the Act - no matter what it says - as authorizing an uncompensated expropriation? Will it hold the expropriation bad, or will it find an obligation to compensate at common law? The latter solution seems attractive In any case it is clear enough that damage caused by legislation is not in general reparable through a court of law; that the question whether the damage is intended to be done or authorized is one of construction; and that, short at least of outright expropriation, it will not be assumed that compensation was a condition of the operation of the legislation according to its tenor. Regulatory legislation, however drastic, must normally be suffered without compensation, unless compensation is specially provided. In particular, the mere ownership of property at the time of new regulations will not itself normally afford a vested right such as must be presumed either exempt from the operation of the legislation or the subject of a right to compensation. In the Supreme Court's jurisprudence many of the best illustrations arise from the regulation of the use and enjoyment of land: Canadian Petrofina v. Martin (1959), ${ }^{62}$ for example, and Taylor Blvd. Realties v. City of Montreal (1963) ${ }^{63}$ which show the two sides of the coin. What are the results? Rent control and security of tenure for tenants of dwellings operate in practical terms, if not in law, as a massive confiscation of private property, for the tenants are in effect given interests in the realty with the obligation to pay less than a free market price. The dwelling becomes in part their own. Too bad if this discriminates as between owners of dwellings and commercial premises. Again, the prohibition to demolish or even alter buildings deemed of aesthetic significance creates a museum at the expense of the unfortunate owner. Too bad if this discriminates in favour of neighbours fortunate enough to have invested in eyesores, or in anything else for that matter. Nor is the unfortunate owner in either case allowed to elect to force the public authority to become owner of the rented premises or of the "museum", - to bear the cost of subsidising dwellings or museums. Legislative justice is normally rough; the popular clamour must be heeded; and the cry is for benefits at somebody else's expense.

Such, then, is the consequences of legislative sovereignty; though the Canadian Bill of Rights, and similar enactments, - unless competently excluded

${ }^{61}$ North Charterland Exploration Co. (1910) Ltd. v: The King, [1931] 1 Ch. 169 at 186-7.

62 [1959] S.C.R. 453 (mere ownership-and even further steps towards use-will not protect from supervening regulation).

63 [1964] S.C.R. 195 (the damage resulting from regulation does not come within a statutory provision for compensation for loss of "vested rights"). 
- may where applicable require other results, in particular by the implication of a condition of compensation. But that depends on the courts.

I promised earlier to return to the proceedings against Prime Minister Trudeau and Premier Bennett, and it is in this connection that I intend to do so. In Roncarellis Case there is an important passage in the reasons of Mr. Justice Rand: ${ }^{\text {st }}$

Mr. Scott argued further that even if the revocation were within the scope of discretion and not a breach of duty, the intervention of the respondent in so using the Commission was equally a fault. The proposition generalized is this: where, by a statute restricting the ordinary activities of citizens, a privilege is conferred by an administrative body, the continuance of that enjoyment is to be free from the influence of third persons on that body for the purpose only of injuring the privilege holder. It is the application to such a privilege of the proposition urged but rejected in Allen v. Flood in the case of a private employment. The grounds of distinction between the two cases have been pointed out; but for the reasons given consideration of this ground is unnecessary and I express no opinion for or against it.

The point is this. M. Archambault's action in revoking (or purporting to revoke) the permit might be held outside his statutory authority for more than one reason. One is the improper purpose for which he employed his powers. Another is the fact (if such was the case) that he did not in truth exercise them himself, but under the influence or dictation of another. In either event, the exercise (or purported exercise) of the power could be held bad. Whether, even where such is the fact, an action in damages always lies is a matter of difficulty. Here is what Professor H. W. R. Wade wrote in 1961:85

... In Canada there has even been a successful action for damages against the Prime Minister of Quebec for directing the cancellation of a liquor licence because the licensee supported the sect called Jehovah's Witnesses - which he was entitled to do, and which had nothing to do with his qualifications for his licence. But in England a similar action would be more likely to reveal the weakness of the action for damages: there must be some actionable wrong, i.e. some recognized tort or some breach of contract. Trespass to person or property is a tort, and so is injury caused by negligence. But there is no tort of 'injury to livelihood" or "loss of licence' or loss of job'. The law in Quebec, modelled on the French principle of giving damages for any injury caused by fault, was more general, so that the action succeeded by the combination of a French principle with an English remedy. But in England, characteristically, the remedy will lie only in a series of recognized cases, and has failed to produce a comprehensive general principle. The gaps in the law of tort are always likely to reveal themselves in connexion with administrative powers, for the old rules of common law do not touch some of the important questions of modern life. Many decisions of ministers, tribunals, or licensing bodies, which may be of the greatest importance to a man's status or livelihood, inflict no recognized legal injury if they are wrongly made. If they are to be challenged and proved to be nullities, some special remedy is required. Although the action for damages therefore plays a central part, it is incapable of dealing with large classes of administrative acts, and other remedies have had to be devised to supplement it.

Ten years later the corresponding passage was to this effect: ${ }^{\circ 8}$

$\therefore$ In Canada there has even been a successful action for damages against the Prime Minister of Quebec for directing the cancellation of a liquor licence because the licensee supported the sect called Jehovah's Witnesses - which he was entitled to do, and which had nothing to do with his qualifications for his licence. The law in Quebec, modelled on the French principle of giving damages for any injury caused by fault, treats wrongful cancellation of a licence as a [sic] actionable wrong, as indeed it may be in England if malice can be shown. But gaps in the categories of the law of tort are always likely to reveal themselves in connexion with administrative powers, for the old rules of common law do not touch some of the important questions of modern life. Many decisions of ministers, tribunals, or licensing bodies, which may be of the

64 Supra, n. 6 at 144.

${ }^{65}$ Administrative Law, (Oxford, 1961) at 83.

${ }^{\circ 0}$ Administrative Law, 3rd ed. (Oxford, 1971) at 110. 
greatest importance to a man's status or livelihood, inflict no recognized legal injury if they are wrongly made. It is true that wrongful administrative action is breach of statutory duty and that breach of statutory duty may be actionable. But the law in this area is uncertain, and a more reliable remedy is required. The action for damages is therefore unsuitable for dealing with large classes of administrative acts. In practice it plays a relatively small role.

Professor Laskin, as he then was, expressed some horror at the suggestion that Roncarelli might not have succeeded in a common-law jurisdiction. The year was 1962 or 1963, and Professor Laskin was on sabbatical leave in England, visiting Oxford for a day or two. I had reminded him of the passage in Professor Wade's book, and proved the point by pulling a copy off the shelves in Blackwell's. My Lord will no doubt be encouraged by the present version, which is however still not without its vestige of caution. An interesting and useful authority contemporary with Roncarellis Case and bearing important analogies with it is Farrington v. Thomson, ${ }^{67}$ a decision of Mr. Justice Smith in the Supreme Court of Victoria. Economic loss caused by intentional but wrongful interference with enjoyment of a liquor license was there held to be actionable.

So much, then, for the case of the public officer who can be blamed for damage flowing from governmental action outside the actor's jurisdiction. What, however, of one to whom is attributable, wholly or partly, the procuring of competent governmental action? That is the hypothesis put to one side by Mr. Justice Rand in Roncarelli v. Duplessis. It is also precisely the case of Roman Corporation and Stephen B. Roman v. Hudson's Bay Oil and Gas Company, The Right Honourable Pierre E. Trudeau and The Honourable John J. Greene (1973). ${ }^{68}$ The plaintiffs claimed damages in the amount of one hundred and four millions from the individual defendants, alleging wrongful procurement or attempted procurement of breach of contract; conspiracy to harm plaintiffs; intimidation of plaintiffs; and unlawful interference with their economic interests. Shortly stated, the plaintiffs had contracted, or were negotiating, the sale into foreign hands of their substantial interests in Consolidated Denison Mines, an important uranium producer. Both inside and outside the House of Commons, the Prime Minister and Mr. Greene, the Minister of Energy, Mines and Resources, made it clear that in their opinion transactions of this nature were contrary to the public interest; and that regulations would be passed or legislation enacted to prevent them. However, assurance was given that binding agreements made before March 2, 1970, the date of the Prime Minister's first statement in the House, would be respected. In the event, no such legislation or regulations became law. But the deal or negotiations were abandoned, even though it was part of plaintiff's case that they had, before March 2, 1970, made a binding oral agreement with Hudson's Bay Oil and Gas, the prospective purchaser. The latter indeed appears as a respondent in the case because plaintiffs sought a declaration against it to this effect.

Could Ministers of the Crown in any event be civilly liable for procuring legislation to the detriment of the plaintiffs? Could they be civilly liable for threatening to do so? Here was the principal issue in the case. Could they have committed a legal wrong by being party to that which in law was no wrong? A man will be civilly liable if he wilfully causes a landslide to come down upon another walking at the foot of a hill. Can governmental action ever be legally similar to a landslide?

Even this sort of claim is not without precedent. In the last century, a curious pair of Canadian cases were reported under the same style, Gregory v.

or [1959] V.R. 288.

B8 [1973] S.C.R. 820. 
Canada Improvement Company. ${ }^{69}$ Plaintiff first sought (in Nova Scotia) to restrain, and then (in Quebec) to obtain damages for, promotion of certain provincial legislation which, he claimed, interfered with his contractual rights to certain mortgage bonds. The action for damages was in fact successful, though the result seems as consistent with a restitution based on frustration as with a condemnation for damages arising from wrongfully procuring legislation. More interesting is Rafael v. Verelst, ${ }^{70}$ in which the English Court of Common Pleas in 1775 held the defendant, the President of Bengal under the East India Company (who was not specially justified on the basis of his authority), civilly liable for having caused (as a jury found) the imprisonment of the plaintiff in a native state under the authority of a native ruler, but by the procurement of the defendant, and under his awe and influence - the ruler acting contrary to his own inclination out of a fear of offending the defendant. Mr. Justice Blackstone, one of four members of the bench, referred to the Nabob as "a mere machine, - an instrument and engine of the defendant."71 These words would have been equally apt to describe the Quebec Legislature under Duplessis. Suppose Duplessis had caused Roncarelli's liquor license to be revoked by statute. Could this have made him liable in damages?

To hold actionable the actual procuring of damaging legislation would stop just short of direct confrontation with the authority of the legislature. I say just short, because the two can - logically - co-exist. The legislation can operate according to its tenor, whilst some individual or public authority is made to pay for it. That would be in its effect rather like a statutory compensation, except that here there is no statutory right to compensation. But if such were the law, all that would be required to protect persons procuring legislation would be the insertion therein of an additional provision indemnifying those involved. It would then become impossible to amerce anyone without thereby refusing effect to the legislation. But it is clear that no such special protection is needed by those party to the enactment of legislation. Legislation is damnum sine injuria. In 1629 Sir John Eliot, Denzil Hollis, and Benjamin Valentine were convicted in the English King's Bench of various offences, particularly seditious words, arising out of events in the House of Commons. In 1667 the Commons protested the judgment as a breach of privilege, and instigated the bringing of a writ of error by Hollis, who had by then become a peer of the realm. The judgment was reversed. In a conference between the two Houses, Vaughan, the Manager for the Commons, first argued that whilst things unlawful could be aggravated by the intent with which they were committed, things lawful could not become unlawful by the intent alone. I quote this for its bearing on the basic liberty of tax avoidance in which I assume we all indulge to some extent: ${ }^{72}$

For Instance, taking away my Horse is a Trespass only; but intending to steal him makes it Felony: Borrowing my Horse, though intending to steal him, is not Felony, because Borrowing is lawful, and there were no Use of Freedom of Speech otherwise; for a depraved Intention may be annexed to the most justifiable action: If a Man eat no Flesh, he may be accused for the depraved Intention of bringing in the Pithagorian Religion, and subverting the Christian. If a Man drink Water, he may be accused of the depraved Intention of subverting the King's Government, by destroying His Revenue both of Excise and Custom.

Then came this memorable passage:

No Man can make a Doubt, but whatever is once enacted is lawful; but nothing can come into an Act of Parliament, but it must be first affirmed or propounded by somebody; so that, if the Act can wrong nobody, no more can the First Propounding:

iy (1879) Russell's Equity Decisions (N.S.) 358 (Ritchie, E.J.); and (1883) $5 \mathrm{La}$ Thémis 10 (Que. S.C.; Jetté J.).

70 (1775) 2 Wm. Bla. 621; 96 E.R. 1055.

71 Id. at 96 E.R. 1059.

72 Lords Journal, (1667-75) at 166; 11 December 1667. 
The Members must be Free as the Houses. An Act of Parliament cannot disturb the State; therefore the Debate that tends to it cannot, for it must be propounded and debated before it can be enacted.

The reasons for judgment of the Supreme Court of Canada in Roman's Case were given by Mr. Justice Martland. In effect they deny that the very enactment of legislation - by which appears to be meant the participating in or procuring of its enactment - can be actionable. But they stop short of denying that a threat or conspiracy to procure it can ever give rise to civil liability: ${ }^{73}$

.. What has occurred here, as stated in the pleadings, is that the parties did not, after the statements made by the respondents, proceed to complete their agreement. Clearly, this was because they apprehended that legislation, by way of regulation or statute, would be enacted to prevent the control of Canadian uranium resources passing from Canadian to non-Canadian hands.

If valid legislation for that purpose were enacted and it prevented performance of a contract for transfer of such control, there is no doubt that the parties to the agreement would have no cause of action arising out of the enactment of such legislation. A statement of policy made bona fide by a Minister of the Crown of the intention of Government to enact such legislation cannot, in my opinion, give rise to a claim in tort for inducing a breach of contract if the parties to the contract elect, in the light of that statement, not to proceed to perform the contract.

The appellants also made a claim in tort for intimidation. In order to succeed under this head, the facts relied upon by the appellants would have to disclose that they had sustained damage by reason of a threat, made by the respondents, of an unlawful act. In my opinion, it cannot be said that a declaration made in good faith by a Minister of the Crown as to Government policy and the intent to implement that policy by appropriate legislation is a threat of an unlawful act. On the contrary, it is part of a Minister's duty to the public to disclose that policy from time to time.

So far as conspiracy was concerned, Mr. Justice Martland, having referred to the decision of the House of Lords in Crofter Hand Woven Tweed Company,

\section{Limited v. Veitch, ${ }^{74}$ continued: ${ }^{75}$}

There is no suggestion in the statement of claim that the actions of respondents, of which it complains, were taken with a view to injuring the appellants. What they were doing was to enunciate a policy in relation to the control of uranium resources in Canada, the effect of which, if implemented, could prevent the performance of the contract.

The appellants seek a declaration that the respondents committed a tort of unlawful interference with the appellants' economic interest. A claim for such interference, in the circumstances of this case, would have to be brought within the scope of one or more of the three causes of action already discussed.

His Lordship concluded by distinguishing Roncarellis Case from that at bar, which was one where "the respondents, as Ministers of the Crown, were acting in the performance of their public duties in enunciating, in good faith, Government policy."

These observations, with respect, seem to me eminently sound. I wish it were possible to leave the matter here, with the disposition of the case on what Mr. Justice Martland rightly calls "the broader issue". ${ }^{76}$ However the courts of Ontario dealt with the action also on points of parliamentary privilege. ${ }^{77}$ Unfortunately their views on this subject give me cause for great concern. More unfortunately still, the Supreme Court, through Mr. Justice Martland, counten-

78 Supra, n. 68 at $829-30$.

74 [1942] A.C. 435.

${ }^{75}$ Supra, n. 68 at $830-31$.

76 Id. at 828 .

77 [1972] 1 O.R. 444; (1971) 23 D.L.R. (3d) 292 (C.A.), affirming [1971] 2 O.R. 418; (1971) 18 D.L.R. (3d) 134 (H.C.; Houlden J.). 
anced these views, without (I hope it will be held) approving them: ${ }^{78}$ "Without dissenting from the views expressed in the Courts below as to the privilege attached to statements made in Parliament, I would prefer to deal with the appeal on the broader issue." So I feel myself compelled to make a few remarks on privilege, too, particularly because in my opinion the Supreme Court should have disapproved the rulings of the court below, or at any rate remained absolutely silent on the subject.

With civil procedure as it exists in modern Anglo-American common law I can claim barely even a rudimentary acquaintance. I have had occasion, however, to read more than a few cases arising from motions to strike statements of claim as disclosing no reasonable cause of action. $\mathrm{My}$ impression is that "demurrer" has become something of a dirty word. "[I]f thine eye offend thee, pluck it out", enjoins the Scripture. ${ }^{79}$ A more avuncular approach must, it seems, be taken to pleadings. I see no reason why particulars should not be demanded and ordered until the nature of the claim becomes completely clear; nor why, if the allegations then prove insufficient in law to justify the relief sought, the claim should not be struck without pity. If, however, loose pleadings are to be tolerated, and the case is to be decided on whatever turns up at trial, pleaded or not, it is easy to see why the courts hesitate to strike out claims immediately on the legal merits. The pleadings cannot be assumed to state the claim.

This case came at first instance before Mr. Justice Houlden in the Ontario High Court as a motion, first to dismiss certain paragraphs, and parts of paragraphs, from the statement of claim; secondly to strike out the whole statement of claim; and thirdly to dismiss the action as against the defendants Trudeau and Greene. One respondent, the Hudson's Bay Oil and Gas, was not party to the motion. So his Lordship confined himself to the first and third prayers. But instead of deciding boldly, as did the Supreme Court, that, on the allegations, there was no civil liability, Mr. Justice Houlden preferred a piecemeal approach, chopping the statement of claim into bits by striking out particular paragraphs on supposed grounds of parliamentary privilege, leaving the whole in such tatters that, " $[w]$ ithout these paragraphs the statement of claim discloses no cause of action against the defendants Trudeau and Greene, and the prayer in the statement of claim in respect of these defendants should, therefore, be struck out and the action dismissed against the defendants Trudeau and Greene with costs." ${ }^{\text {go }}$ The portions struck out fall (as Houlden J. held) broadly into two categories. The first consists of allegations of statements made on the floor of the House of Commons of Canada; the second of statements outside the House. As regards the first category, I accept that the privilege of the United Kingdom House of Commons and its members may be such as to preclude (at all events without the consent of the House) proof in courts of law of debates and proceedings in Parliament, even where these words or proceedings are not themselves the basis of the cause of action (as they are for example in defamation) and even where the cause of action arises entirely outside the House. ${ }^{81}$ Frankly, I suspect that when the question finally gets to the House of Lords this doctrine stands more than a chance of going the way of Duncan v. Cammell Laird. ${ }^{82}$ Still, the Ontario courts were quite entitled to follow the authorities

\footnotetext{
78 Supra, n. 76.

79 Mark, 9:47.

80 [1971] 2 O.R. 418 at 427.

81 Church of Scientology of California v. Johnson-Smith, [1972] I Q.B. 522.

82 [1942] A.C. 624; which was confined to its facts, and its exposition of the law repudiated in substance, by Conway v. Rimmer, [1968] A.C. 910.
} 
as they stand now. Since by statute ${ }^{83}$ the Senate and House of Commons of Canada and their members enjoy in this respect the same privilege as the Commons at Westminster, it followed that those paragraphs of the statement of claim alleging speeches in the House would be struck out.

But the position of statements in the second category, - those made outside the House, - is quite another matter. Here there were in particular a telegram from Mr. Trudeau and a press release from Mr. Greene. Mr. Justice Houlden held that they were "only extensions of statements made by the defendants Trudeau and Greene in the House of Commons, and, therefore, come within the privilege ... regarding statements made in the House of Commons. ${ }^{84}$ The Ontario Court of Appeal, in which Aylesworth J.A. spoke for himself and McGillivray and Jessup, JJ.A., approved the reasoning of the trial judge. The Court agreed that the telegram and press release were "mere extensions of statements made by the respondents in the House, and, therefore, were protected with the same absolute privilege as those communications made in the House itself." 85

Now both at trial and on appeal the Senate and House of Commons Act was referred to and even quoted. Suppose we actually read the Act and see what it says. Sections 7 to 9 deal with reports, papers, votes and proceedings published under the authority of the Senate or the House of Commons. Section 7 gives absolute privilege to publishers of the originals, and section 8 gives the like privilege to those who publish any copy. Then comes section 9:

9. In any civil or criminal proceedings commenced or prosecuted for printing any extract from or abstract of any such report, paper, votes or proceedings, such report, paper, votes or proceedings may be given in evidence, and it may be shown that such extract and abstract was published bona fide and without malice, and, if such is the opinion of the jury, a verdict of not guilty shall be entered for the defendant.

Is the effect of section 9 not obvious? Should it not have alerted the judges immediately to the impossibility of their position? If Mr. Trudeau and Mr. Greene had handed out extracts from Hansard reporting their very statements on the floor of the House, word for word, they would have enjoyed qualified privilege only. The Act says so explicitly. Yet we are asked to believe that their press statements and telegrams, which might or might not repeat what was said in the House, stand in law on a higher footing than extracts from Hansard. While extracts from Hansard enjoy qualified privilege only, telegrams and press releases, it is solemnly held, enjoy absolute privilege. Of course such a result would be perfectly ridiculous, and could only exist if Parliament, in enacting s. 9, had misconceived what the law would otherwise be, and by mistake reduced an absolute privilege to a qualified one as regards extracts from reports, papers, votes and proceedings.

In truth, as even a cursory examination of the authorities will show, Parliament did no such thing. The Parliament of Canada simply followed the language of the Parliamentary Papers Act, $1840,{ }^{86}$ which the United Kingdom Parliament had enacted to remedy the law laid down in Stockdale v. Hansard. ${ }^{87}$ In that famous case the Court of Queen's Bench held first, that it was up to the

8s Senate and House of Commons Act, R.S.C. 1970, c. S-8, s. 4.

84 [1971] 2 O.R. 418 at 426.

85 [1972] 1 O.R. 444 at 450.

863 \& 4 Vict., c. 9 (U.K.).

87 (1837) 9 A. \& E. 1; 112 E.R. 1112. 
courts to decide whether a claim of privilege was well-founded in law, and second, that the order of the House of Commons could not protect persons publishing outside the House a report ordered by the House to be printed. Clearly, the strictest possible view of privilege was taken in Stockdale v. Hansard. Yet the case is cited both by Houlden J. and Aylesworth J., even though it stands, if anything, for the exact opposite of their position on statements made outside the House. For this sort of oversight it is not easy to find an explanation consistent with the respect due to the judges of these courts. And the standard text-books and works of reference offer more authorities besides. In the Strauss Case (1958), ${ }^{88}$ the United Kingdom House of Commons held that a letter written by a Member to a Minister reflecting on a nationalized industry was not a proceeding in Parliament. There was a closely similar decision in 1936 in the Quebec Superior Court: Vézina v. Lacroix. ${ }^{89}$ It is not everything done in one's capacity as a Member that is a proceeding in Parliament. Nor is everything done by a Minister done in his capacity as a Member. Yet all these are thoroughly confused in the two courts.

In both the High Court and the Court of Appeal there is talk of principle and policy. Suppose we look at principle and policy. What is the need of absolute privilege for telegrams and press releases? Why is qualified privilege ${ }^{90}$ not enough? Absolute privilege is drastic. Qualified privilege admits of nuance. Must we have a series of cases in which the courts, having committed themselves to an absolute privilege, desperately twist and turn the definition of the occasion to coincide with their views of the defendant's good faith in a given set of facts - and end up with a qualified privilege masquerading as an absolute privilege? Surely when Roman's Case reached the Supreme Court somebody on the bench remembered Jones v. Bennett. ${ }^{91}$ After all, that had been decided only five years earlier, in 1968. Mr. Jones had been Chairman of the Purchasing Commission of British Columbia. The Attorney-General caused criminal charges to be laid against him, alleging unlawful acceptance of benefits. The charges were dismissed. So was an appeal, on the ground that it was frivolous and vexatious. Mr. Jones, who held office on good behaviour subject to removal by the Lieutenant-Governor in Council on address of the Legislative Assembly, declined to vacate his office in obedience to an Order in Council passed at the time charges were laid against him, and purporting to relieve him of his duties until further order. Bill 34 was introduced into the Legislature, entitled An Act to Provide for the Retirement of George Ernest Pascoe Jones. The rest of the facts are as stated by Chief Justice Cartwright for the Supreme Court of Canada:02

On March 5, 1965, when Bill 34 was still under debate in the Legislature, the defendant, who was and is the Premier of British Columbia, addressed a meeting of the Social Credit Association at Victoria, B.C., concerning various matters relating to the public affairs of the Province of British Columbia and of political interest and concern to the electors and to the members of his party. Most of the persons present were either members or supporters of the Social Credit Party. The Attorney-General and the Minister of Mines as well as several members of the Legislature were present. Two newspaper reporters were also present. The defendant spoke to the meeting briefly commenting on several matters that were then of current interest to the public including the proposed Bank of British Columbia, the generally bright future of the province, the year's budget and the conduct of the members of the opposition parties in the

${ }^{88}$ See O. Hood Phillips, Constitutional and Administrative Law (5th ed., 1973) at 201-2. 80 (1936) 40 R.P. 1.

${ }^{90}$ See e.g. Beach v. Freeson [1972] I Q.B. 14.

91 [1969] S.C.R. 277.

92 Id. at 279-80. 
Legislature. During his speech the defendant also made reference to the plaintiff and to the action of the government in introducing Bill 34 with respect to him and, as found by the learned trial Judge, used the following words: "I'm not going to talk about the Jones boy. I could say a lot, but let me just assure you of this; the position taken by the government is the right position".

The bill became law. Mr. Jones brought action for slander against Mr. Bennett, who did not attempt to justify his comments, but instead pleaded amongst other things qualified privilege and fair comment. Plaintiff was successful at trial; defendant on appeal; plaintiff in the Supreme Court of Canada. The Supreme Court rejected the plea of fair comment. More to our purposes, it denied that the occasion was one to which even qualified privilege attached. Chief Justice Cartwright spoke for the Court when he said that ${ }^{\circ 3}$ "assuming, although I am far from deciding, that had no newspaper reporters been present the occasion would have been privileged, I am satisfied that any privilege which the defendant would have had was lost by reason of the fact that, as found by the learned trial Judge, "The Premier must have known that whatever he did say would be communicated to the general public. The two reporters sat at a press table in full view of the speaker's table." " In other words, Premier Bennett had published his words "to the world". The Court, so far from finding the presence of reporters a fact favouring the privilege, fixed upon it as the very reason why any privilege which otherwise might have attached was lost. And the privilege, even if it did exist, would have been qualified only. There is no talk here about "mere extensions" of what had been said in the Legislative Assembly. ${ }^{94}$ And suppose that Premier Bennett, instead of addressing a political meeting, had issued press releases from his office. Would this have converted the case from one of no privilege at all to one of absolute privilege? of course it would not. There is no material difference between the two cases. Both are publications "to the world". Neither is part of parliamentary proceedings. Absolute privilege is extreme and highly extraordinary. The law dispenses it very rarely and very grudgingly. Three judges who sat in Jones's Case sat also in Roman's Case: Martland, Judson, and Ritchie, JJ. Would it have been too much to ask that they, or Chief Justice Fauteux, or

08 Id. at 284.

o4 The absolute privilege attached to legislative proceedings in British Columbia now is governed by the Legislative Assembly Privilege Act, R.S.B.C. 1960, c. 215, ss. 2 and 5 . It will be recalled that, under the rule in Kielley v. Carson (1841-2) 4 Moo. P.C. 63; 13 E.R. 225, Commonwealth legislative bodies enjoy at common law not the privileges of the Lords or Commons at Westminster, but only those necessarily implied by their creation as legislative bodies. What privileges these are is the subject of a very extensive jurisprudence. This is true whether the bodies are representative (Kielley v. Carson) or non-representative (Chenard v. Arissol [1949] A.C. 127); whether summoned by the Crown in exercise of the royal prerogative (Kielley v. Carson) or created by Imperial statute (Fenton v. Hampton (1858), 11 Moo. P.C. 347 at p. 397; and whether erected in settled territories (Kielley v. Carson) or in conquered or ceded territories (Doyle v. Falconer (1866) L.R. 1 P.C. 328; Chenard v. Arissol, supra.) The rule in Kielley v. Carson is perhaps the one most completely settled in all our constitutional law, and has been applied systematically by the courts throughout the Commonwealth, including the Privy Council which established the rule in the first place, and the Supreme Court of Canada: Landers v. Woodworth (187778) 2 S.C.R. 158. The privilege of free speech is one that does attach as a necessary, common-law, incident to all legislative bodies and enures to the individual members to protect them from actions and prosecutions for defamation for words spoken in the House; the privilege is not qualified but absolute: Gipps v. McElhone (1881) 2 N.S.W.R. 18, approved by the Privy Council in Chenard v. Arissol, supra. Competent legislation can of course extend the scope of privilege, and the Legislative Assembly Act of British Columbia now does so. On the scope of provincial legislative jurisdiction to confer privileges on the houses or members of the provincial Legislature, the leading authority is of course Fielding v. Thomas [1896] A.C. 600. The federal legislative authority is governed by s. 18 of The British North America Act, 1867, subject to section 91 , head 1 . 
Justice Abbott, Spence, or Laskin, who made up the bench of seven in the latter appeal, should see immediately the implications of the decision of the Ontario courts on the privilege issues? That holding was demonstrably an outrage upon principle and a travesty of the authorities. Was that not clear from the argument? Was it not clear equally on the very face of the Senate and House of Commons Act? If their Lordships wished to express no opinion on the parliamentary privilege issue, why not maintain strict silence? The words employed by Martland J. for the Court are bound to be understood as giving countenance to the view of the Ontario Courts. The development of the law is gravely prejudiced. For instance, the next case is as likely as not to arise from the televising of legislative proceedings before the provisions protecting publication of parliamentary papers are expanded to cover broadcasts, - and the courts will want some excuse to find for the defendants.

Every time I pick up the law reports I am impressed anew with the fact most that the decisions of Canadian courts are as often as not full of mistakes of the most elementary kind. The errors of lower courts can be corrected in the Supreme Court of Canada, but only the Supreme Court can correct its own. There is in my respectful opinion no tribunal in this country which can reasonably refuse to reconsider its decisions where that is necessary to correct error. It seems to me time for the Supreme Court to acknowledge this frankly. We as law teachers are, I fear, to blame as well. It is at present unfashionable to insist on the mastery of large amounts of black-letter law, especially in areas not for the moment chic. How many constitutional law teachers taught the War Measures Act before 1970 (and I do not mean merely the federal legislative power to deal with emergencies; I mean the Act)? How many now teach parliamentary privilege? There is a widespread attitude that Canadian constitutional law consists almost exclusively of the provisions governing distribution of legislative and executive authority. Institutions are neglected. I wish I could say that my Lord the Chief Justice discouraged this attitude. How many of the eleven judges who in three courts heard Roman's Case and they include my Lord - have ever actually read Stockdale v. Hansard before, during, or after the hearing of Roman's Case?

\section{Access to the Courts}

One of the cardinal principles of the rule of law, as Dicey understood it, was that" "every man, whatever be his rank or condition, is subject to the ordinary law of the realm and amenable to the jurisdiction of the ordinary tribunals." Obviously, public authorities are distinguished precisely by the fact that they wield powers not enjoyed by others. One can therefore quibble about what "ordinary law" means, and depending on whether the term is widely or narrowly understood, find Dicey's proposition to be either a truism or outright nonsense. It is easy to argue about the meaning of "ordinary tribunals". Nevertheless, the principle as stated by Dicey can be applied to measure the stand taken by the common and statute law on a number of issues which concern access to the courts. I wish to say something here about judicial jurisdiction and "privative clauses", using that term in a comprehensive sense.

The Supreme Court of Canada stands at the apex of the judicial system. As such it is the ultimate guarantor of the rule of law as Dicey understood it. At the outset of my talk I quoted the bold words of certain sections of the Supreme Court Act. Those provisions do not (it seems) actually confer 
jurisdiction. Section 41, however, does. As newly enacted on 20th December, 1974, and now in force, subsection (1) of section 41 reads as follows: ${ }^{98}$

41. (1) Subject to subsection (3), an appeal lies to the Supreme Court from any final or other judgment of the highest court of final resort in a province, or a judge thereof, in which judgment can be had in the particular case sought to be appealed to the Supreme Court, whether or not leave to appeal to the Supreme Court has been refused by any other court, where, with respect to the particular case sought to be appealed, the Supreme Court is of the opinion that any question involved therein is, by reason of its public importance or the importance of any issue of law or any issue of mixed law and fact involved in such question, one that ought to be decided by the Supreme Court or is, for any other reason, of such a nature or significance as to warrant decision by it, and leave to appeal from such judgment is accordingly granted by the Supreme Court.

Subsection (3), of course, excludes any appeal under this section "from the judgment of any court acquitting or convicting or setting aside or affirming a conviction or acquittal of an indictable offence or, except in respect of a question of law or jurisdiction, of an offence other than an indictable offence." Appeals on indictable offences are permitted by the Criminal Code, ${ }^{97}$ but as it is questionable whether that is as comprehensive as could be wished (would it for instance embrace a provincial penal offence made triable on indictment?). I should be happier if all relevant provisions were framed in wide terms and collected in the Supreme Court Act.

But I have digressed from section 41. It confers a generous jurisdiction. It is only a little unfair to say that it has been forced on an unwilling court. My impression of the history of its predecessor provisions is that the Supreme Court of Canada has adopted a grudging attitude towards its own jurisdiction, ${ }^{88}$ and towards the granting of leave. ${ }^{.0}$ The decisions of the Judicial Committee ${ }^{100}$ have permitted the Parliament of Canada constitutionally to put the Supreme Court in an impregnable position. Section 101 of the Act of 1867 enables Parliament to define the Court's jurisdiction notwithstanding provincial interference, and, with the Statute of Westminster, 1931, to make it the final tribunal of appeal. What may be the effect (should it ever be suffered to become law) of that dog's breakfast of shortsighted political compromises called the draft Canadian Constitutional Charter, produced by the 1971 Constitutional Conference at Victoria, ${ }^{101}$ I do not venture to suggest. But I have no hesitation in insisting that, so long as the Act of 1867 and the Supreme Court Act read as they do now, the appellate jurisdiction of our final tribunal must not be undermined. I therefore consider the Supreme Court's decision, now ten years old, in J. R. Théberge Limitée v. Syndicat National des Employés de lAlumnium dArvida ${ }^{102}$ to be distinctly less than astute. The Quebec Labour Relations Board was held not to be a court within s. 41(1) of the Supreme Court Act in 1965. An application for leave to appeal from the board was therefore dismissed. I myself cannot see why a body which is a "court" for

8623 Eliz. II, S.C. 1974, c. 18.

97 R.S.C. 1970 , c. C-34, s. $618 \mathrm{ff}$.

98 Danjou v. Marquis, (1879) 3 S.C.R. 251; International Metal Industries Ltd. v. City of Toronto, [1939] S.C.R. 271; Furlan v. City of Montreal, [1947] S.C.R. 217.

${ }^{09}$ Major v. Town of Beauport, [1960] S.C.R. 60.

100 Supra, n. 1.

101 Conveniently reprinted, as Appendix B, in the Final Report of the Special Joint Committee of the Senate and the House of Commons on the Consitution of Canada, 4th Session, 28th Parliament, 1972. Part IV of the "Charter" deals with the Supreme Court, and Art. 35ff. with its jurisdiction. Art. 59 and the Schedule would repeal s. 101 of the Act of 1867.

102 [1966] S.C.R. 378. 
the purposes of certiorari should not also be held to be a court within s. $4 I(1)$. Anyone who exercises powers which, in contemplation of law, are judicial powers is, generically, a court. To permit nomenclature to be decisive would subvert the Supreme Court Act and section 101 of the Act of 1867. Mr. Justice Fauteux, as he then was, speaking for a panel of three, of whom the others were Abbott and Hall, JJ., seemed to rely on the enumeration in the provincial Courts of Justice Act to show what is a "court" within the contemplation of the Supreme Court Act. They also contrast administrative and judicial tribunals as if the two were mutually exclusive. If such considerations are permitted to govern, their Lordships will see how effectively this escape route can be employed by any legislature determined to reduce the Crown Grain Case $\mathrm{Cas}^{103}$ to a dead letter. The spectre of inundation by applications for leave may have played more part than it ought when, in the past, the Court has had to rule on its own jurisdiction. With a greater freedom now to choose the cases it will hear, perhaps it will adopt a different attitude. Most applications for leave to appeal from specialized tribunals may have to be refused, but the power to grant them must be held in reserve. Only so can the Supreme Court defend itself. Its occasional exercise of jurisdiction on such applications, and indeed on applications for leave to appeal from "courts" eodem nomine at the lowest level of the judicial hierarchy when their decisions are not otherwise appellable, would go far to curb arbitrary and lawless behaviour in such bodies. On the strict doctrine of precedent, the interpretation of s. $41(1)$ is again res integra, because the subsection is, formally, a new one, even if unaltered in the material particular. I hope that their Lordships, perhaps sitting in a full bench, will depart from the Théberge decision. I venture in any case to hope that in no event will s. 101 be interpreted in a similarly restrictive way; for that, I think, would be fatal. It is not out of place to observe that in Toronto Railway v. City of Toronto, ${ }^{104}$ the appellate jurisdiction of the Queen in Council was held to embrace the Railway Board of Canada. Viscount Finlay, for their Lordships, ${ }^{105}$ pointed out that the prerogative of granting special leave to appeal was "prima facie, applicable to all Courts in His Majesty's Dominions, and their Lordships cannot see any ground which would warrant them in holding that the Railway Board is exempt from the general rule", though the power was one which "in the case of the Railway Board, should be very sparingly exercised". Between the Railway Board and the Quebec Labour Relations Board there was, it is true, this difference, that the Board had by statute been declared a court of record. But it cannot be contended that $s$. 41(1) extends only to courts of record. If that is so, there is no reason why it should not extend to any body of a kind amenable to certiorari, whether or not formally called a "court".

I have so far dwelt on appeals. But the rule of law is secured by the Supreme Court, and other superior courts, also through more limited forms of review. When authorities other than superior courts make "General Confession", admitting that "We have left undone those things that we ought to have done, And we have done those things which we ought not to have done,"100 they are properly to be visited (other remedies aside) with mandamus or injuction for the former, and certiorari, prohibition, or injunction for the latter.

In recent decades we have become increasingly familiar with provisions of various kinds, aimed at excluding recourse to the courts of law for enforce-

103 Supra, n. 1.

104 [1920] A.C. 426.

105 Id. at 434.

108 The Book of Common Prayer; from the order of service for Evening Prayer. 
ment of legal rights. The greatest need of such recourse will often occur where bad administration and bad legislative policy coincide, and the statute book becomes littered with "privative clauses". In Quebec there are even three in the Public Protector Act ${ }^{107}$ to shield the provincial ombudsman. I wonder whether the Quebec parliamentary draftsmen have standing instructions to insert them everywhere, or whether each represents a separate ministerial instruction or draftsman's personal frolic.

In the Jehovah's Witness cases of the nineteen fifties the Supreme Court confined in narrow compass various statutory protections available to public officers sued for damages. Under one Act, a person "in the performance of his public duty" was entitled to a short prescription, or limitation, on actions brought against him. Under another a "public officer or other person fulfilling any public function or duty" had the right to special notice before he could be sued for damages "by reason of any act done by him in the exercise of his functions". Defendants who claim these privileges received short shrift when they had acted in bad faith or without probable cause. They were outside their public functions. The landmark cases are Chaput v. Romain (1955), ${ }^{108}$ Lamb v. Benoit (1959) ${ }^{109}$ and, again, Roncarelli v. Duplessis (1959)..$^{110}$ They follow the settled construction of similar legislation in England, and probably go as far as to require honest belief in a state of facts which would justify the officer in acting - error of law being thus unprotected.

So much else that is instructive and valuable in these cases tempts us to dwell longer than time permits. I would invite reflection on the implications of the incredible, illiterate, Provincial Police Report set out in Mr. Justice Kellock's reasons in Chaput's Case, ${ }^{111}$ and ask what sort of police we need, want, and are prepared to pay for. And I would offer Mr. Justice Taschereau's description of the Jehovah's Witnesses in Chaput's Case ${ }^{112}$ (where he concurred in a decision condemning in damages police officers who wantonly broke up a lawful religious meeting in the plaintiff's house) for comparison with his Lordship's characterisation of the Witmesses in Roncarelli's Case ${ }^{118}$ (where he dissented).

At least since 1874, when the Judicial Committee of the Privy Council decided Colonial Bank of Australasia v. Willan, ${ }^{114}$ it has been clear that enactments excluding the prerogative remedies in respect of the acts and decisions of a public authority, or otherwise insulating its acts from review, will not avail when there is absence or excess of jurisdiction. That, of course, is one of the special canons of statutory interpretation to which I referred earlier. ${ }^{115}$ It is in principle well accepted by the Supreme Court of Canada, which has applied it recently, for example, in Metropolitan Life Insurance Company v. International Union of Operating Engineers, Local 769 (1970).116 In my view the rule should be applied mechanically. If it is not, the inevitable

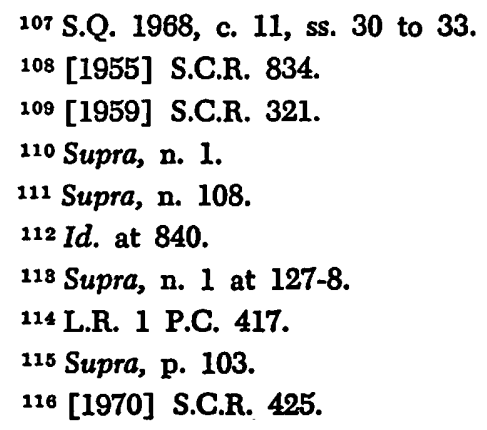


inference must be that judicial review is excluded when the courts are disposed to see it excluded, and available when they are so inclined. Then there is no rule at all; no basic safeguard; only caprice. To be tempted from the rule by the allure of some fleeting convenience appears to me shortsighted. I am prepared to assume, with the majority of the Court in Sanders v. The Queen $(1969)^{117}$ that convenience did point towards allowing the privative clause now found in s. 710 of the Criminal Code to exclude certiorari even where the conviction order in question might be bad for want of jurisdiction. I am prepared to assume, too, that the due administration of justice was satisfied by the right of appeal, and that Sanders deserved all he got. Still, I submit, whatever might have been true of the short run, the long-run interests of the law would have been served by refusing to allow the exclusion of certiorari where jurisdiction was in question. I am glad to see that there was only a majority of one, in a full bench, for what I consider to have been a grievously wrong position, and the more unfortunate because the point was unnecessary to decide given the majority's view of the merits. The actual result would have been the same in any event. I should be glad to think that the Court would reconsider. It can do so, as I say, the more easily since it took the view, on the merits, that the applicant had received the notice to which he was entitled before the order against him (or was presumed in the circumstances to have received it, or had by his conduct competently waived it) - so that there was no defect of jurisdiction at all. Before leaving the Sanders case I would only observe that, if the magistrate's warrant of committal was bad for want of jurisdiction, it was a nullity, which could afford no answer to a writ of habeas corpus, whether certiorari was or was not sought, and whether certiorari was or was not available. Certiorari, however appropriate, and however convenient, can, on principle, never be necessary in such circumstances.

The other decision to which I take respectful exception is Ministre du Revenu National v. Lafleur (1964), ${ }^{118}$ where the jurisdiction of the Quebec Superior Court to issue prerogative remedies in criminal or supposed criminal matters, though admitted to have existed since prior to Confederation, was held to have been excluded by the Criminal Code in favour of an exclusive jurisdiction in the Court of Queen's Bench (Crown Side). Yet there was not in the Criminal Code a single word actually inconsistent with the continued existence of the Superior Court's jurisdiction. Not a word literally abolishing it. Mr. Justice Fauteux admitted as much ${ }^{110}$ when, speaking for the Court, he said that one must "infer" from the Code that Parliament no longer "recognized" the jurisdiction because it had dealt extensively with the prerogative writ jurisdiction of "superior courts of criminal jurisdiction", which, as to Quebec, was defined by statute to mean the Queen's Bench (Crown Side). Parliament had remained silent as to any other jurisdiction. So, the court deduced, there could be no other jurisdiction. Now that is not abolition by express words. That is abolition by inference. That is abolition just because the Court thinks it tidier to have only the one court issuing prerogative writs in criminal, or supposed criminal, matters. One court for civil matters. One court for criminal matters. A tidy exercise in law reform - or so one is supposed to think. As I have already indicated, I consider this objectionable as undermining the rule against exclusion of prerogative remedies. But more than this, it strikes me as a shortsighted and misguided conception of convenience. Convenience does not lie in separating

117 [1970] S.C.R. 109. The majority consisted of Fauteux, Abbott, Martland, Judson, and Ritchie, JJ. The dissentients were Cartwright, C. J., and Hall, Spence and Pigeon, JJ. 118 [1964] S.C.R. 412.

119 Id. at 421 . 
superior courts of civil and of criminal jurisdiction. Convenience lies in making sure that there is at least one court where prerogative writs can be obtained free from jurisdictional problems. That court could have been the Superior Court. Why should the Supreme Court interfere by a forced construction of the Criminal Code, even if the truth was that Parliament had overlooked the Superior Court's jurisdiction? Take habeas corpus, the most famous of the prerogative remedies, the process by which one man who detains another is called upon to justify that detention as well in law as in fact. By habeas corpus Her Majesty, through her courts, inquires into the reasons why any of her subjects is detained. If Her Majesty in her judicial capacity inquires, surely she does not already know. It must on principle be the fact of detention which is the basis of habeas corpus. That fact by itself justifies in law the issuance of the writ. What is the applicant to know, at the time of applying for the writ, of the reasons which the respondent may offer by way of justification of the detention? Perhaps the applicant usually does in fact know. Perhaps procedural convenience dictates that the courts insist on candour in applications. Perhaps when the applicant knows, he ought to tell. Perhaps it is ordinarily a bad thing for the writ to issue out "as of course" and for the merits to be debated on the return. But sometimes the applicant will not know. Detention once proved, it is to the respondent to justify. Why should the jurisdiction of the court depend on the defences which he may choose to offer? A man called upon to justify the detention of a child, might defend on the basis of his rights, under the common or statute law of the province, to custody, care and control of the child. Or perhaps on the basis of an order made under provincial welfare legislation. Or an order under federal criminal legislation. Or an order under provincial penal legislation. Why and how can - or should - the applicant be expected to know - or care - what the defence or defences will be? Why should the procedure or jurisdiction of the court depend on the defences which happen to be made? Has not the applicant some right to know at the outset where to apply?

It is, I confess, a long time since I have read either the House of Lords' decision in Amand's Case ${ }^{120}$ or the Supreme Court's in Storgoffs Case. ${ }^{121}$ I am not in a position to indulge in exegesis of either. I remember feeling that neither really came to grips with the problems of principle. Perhaps they settle the law. Perhaps they settle the law correctly. If so, prerogative writs are criminal proceedings, and unavailable in civil courts, whenever they involve criminal or supposed criminal matters. Then all the more reason to ensure that one court can be found which is capable of exercising both jurisdictions. In Quebec that is now the Superior Court, since its statutory amalgamation ${ }^{122}$ with the Queen's Bench (Crown Side). So the mischief of Lafleur's Case is ended. And mischief I think it was. For who knows even now whether an order detaining a witness at a provincial public inquiry - or a federal inquiry for that matter - is a civil or a criminal matter? Does it depend on the purpose of the committal? And what is to be done with provincial penal matters? ${ }^{123}$

120 [1943] A.C. 147.

121 [1945] S.C.R. 526. The Supreme Court of Canada should never have reached the merits of this case. It was exercising an original jurisdiction. Storgoff had been committed by the order of a superior court, the British Columbia Court of Appeal, a court of co-ordinate jurisdiction with the Supreme Court of Canada. The Supreme Court of Canada had no right to act as if it were hearing an appeal.

122 By An Act to amend the Courts of Justice Act . . [etc.], S.Q. 1974, c. 11, of which the relevant provisions have been proclaimed in force effective March 1, 1975.

${ }^{123}$ See, e.g., Chung Chuck v. The King, [1930] A.C. 244; Nadan v. The King, [1926] A.C. 487. They are generically "criminal", though subject to provincial legislative authority. Which provincial superior courts - civil or criminal - properly have jurisdiction? 
The problems created by Amand's and Storgoff's Cases will be with us in other forms for a long time to come. It would be good to find some rationale which justifies their nuisance.

Now it may be that the prerogative writs produce certain effects in rem on the orders (or purported orders) against which they are directed. ${ }^{124}$ These are very technical matters perhaps now best avoided. In a summa divisio of the law into civil and criminal, such effects might possibly justify characterising the writs as criminal proceedings when employed in criminal (or supposed criminal) matters. On such a view, the effects of prerogative writs on criminal proceedings would be deemed too drastic to permit the writs to be characterised as anything but criminal proceedings when so employed. (It must in any case be obvious that Parliament can, constitutionally, devise remedies of any kind in relation to criminal proceedings, whether or not they have the form or nomenclature of the traditional prerogative writs, and whether they are concurrent or exclusive.) I submit, however, that the mere presence of some impact on criminal proceedings cannot, of itself, be decisive as to the characterization of a remedy, and still less the characterization of the right in respect of which it exists. Actions for damages against constables or magistrates constitute interventions into the administration of the criminal law - very serious interventions. They could bring it to a halt. But damage actions are not the less civil proceedings on that account. Damage actions are no whit the less civil proceedings merely because Parliament can, and does, provide those engaged in the administration of the criminal law with statutory justifications which happen to be found in the Criminal Code. (Indeed, if Parliament thought fit to impose on constables and magistrates an expanded statutory liability in certain circumstances, we would not normally call that a criminal liability.)

What then is the nature in Canadian law of the right to personal freedom? A man may assuredly have a right, within the scheme of the criminal law, to be freed of its toils. Let us, if we will, call that his "criminal law" right to personal liberty. I resent, however, and find objectionable, the suggestion that he does not have a civil right to his personal liberty. I think he does, and none the less when he seeks specific performance rather than damages to vindicate it. The justification offered for detaining him does not change the nature of his basic civil right. I have therefore some difficulty with this observation by Mr. Justice Rand in Storgoff's Case: ${ }^{125}$

We speak of a right in the individual to personal liberty, of a right to the issue of the writ of habeas and a right to be discharged from illegal detention. The basis for asserting freedom from restraint, whether conceived to be the creation of law or to be the result of an original absence of any warrant under law to interfere with liberty, is postulated as a primary right in the juridical system by which we are governed. In that sense, the positive law, in its relation to individual liberty, creates the justification for encroachments upon it. What is important here is the remedial civil right to protection against any other than those legal encroachments and the procedure by which it is enforced; and, within limits, that is what is furnished by the law of habeas. It is not, however, the abstract right to be free that is in question but the right to be free from the particular process.

It seems to me most unsatisfactory.

I referred at the outset to my Lord the Chief Justice as a member of at least three courts. ${ }^{126}$ The one I did not specify was the Canadian Judicial Council, created by the Judges Act. ${ }^{127}$ When making an inquiry or investigation under section 31 , it "shall be deemed to be a superior court". ${ }^{128}$ Whatever

124 For some limits to this doctrine, see Sleeth v. Hurlbert (1895) 25 S.C.R. 620. 125 Supra, n. 121 at 578.

126 Supra, p. 98.

127 R.S.C. 1970 , c. J-I, as amended by R.S.C. 1970 , c. 16 (2nd Supp.).

128 Section 31(4) of the principal Act, as amended. 
its other purposes, that was probably intended to prevent my Lord and his colleagues on the Council from being haled into Federal Court to do penitence. Whoever is to serve, so to speak, as papal confessor, it is not to be Chief Justice Jackett.

I employ this curiosity to illustrate an attribute unique to superior courts, an attribute that distinguishes them not only from all other courts, but from all other organs of the state, - legislative and executive, as well as judicial. Of all authorities in the state, I submit, they, and they alone, have the right to determine conclusively the extent of their own jurisdiction, so that their errors as to their jurisdiction are errors within jurisdiction. And if I am right the consequence is this. All the acts of other authorities, when in excess of jurisdiction, are nullities. As such they are subject to collateral challenge. But the acts of superior courts are never nullities, and may be redressed only on appeal. Indeed, this characteristic of superior courts forms the essential foundation of their supervisory jurisdiction. I understand the recent decision of the Supreme Court in Québec Telephone v. Bell Telephone Company of Canada (1971) ${ }^{129}$ to be an application of these principles. I regret that the dissentient minority allowed their view that the claim for an injunction was unfounded - perhaps manifestly unfounded - to lead them to the conclusion that the Superior Court was without jurisdiction. It is one thing to strike a claim as unfounded - or even as frivolous. That is a disposition on the merits. It is another to decline jurisdiction.

Now if I am right, these principles, properly applied, have momentous consequences for the rule of law in Canada. For if the power conclusively to determine one's own jurisdiction is an attribute historically unique to superior courts, a legislative authority which cannot fully constitute a superior court cannot allow a public authority to become a law unto itself.

I can see nothing in The British North America Act, 1867, that can by reasonable construction stop the Parliament of Canada from making anybody it pleases into a superior court. Nothing in section 101 of the Act of 1867 requires judges of federal superior courts to be persons appointed in a particular manner or with particular qualifications. Long before section 99 was amended by the Imperial Parliament to impose a seventy-five year retirement age on the good-behaviour tenure of provincial superior court judges, the Parliament of Canada deemed itself free to fix whatever tenure it thought fit for the judges of the courts of Canada, and so to oblige the judges of the Supreme Court themselves to retire at age seventy-five. ${ }^{130}$ What would prevent legislation imposing tenure at pleasure? Nothing. Any functionary holding office at the pleasure of the Crown can, in principle, therefore be a superior court judge. Every Minister can be a superior court judge, as can every civil servant. There is nothing impossible about an executive officer being a judge. My Lord is himself a Privy Councillor, and has acted as Administrator of the Government of Canada: as chief executive officer under the Sovereign. It is true that such judges - or, if you prefer, "judges" - can administer none but the "laws of Canada" - for such are the words of section 101 of the 1867 Act. But once constituted judges of superior courts, their acts become unreviewable save on appeal, - and appeals exist at the pleasure of Parliament. If that is true of any federal superior court - the Federal Court of Canada, for example, ${ }^{131}$ - it must be true of all. That, I submit, must be the basis of the Supreme Court's

120 [1972] S.C.R. 182.

180 An Act to amend the Supreme Court Act, 17 Geo. V, S.C. 1926-7, c. 38.

181 See s. 3 of the Federal Court Act, R.S.C. 1970, c. 10 (2nd Supp.). 
decision in Pringle v. Fraser (1972). ${ }^{132}$ The Immigration Appeal Board was by federal statute made a "court of record" and given "sole and exclusive jurisdiction to hear and determine all questions of fact or law, including questions of jurisdiction, that may arise in relation to the making of an order of deportation" and one other matter. That, it is true, stopped short of trying to make the Board a superior court for general purposes. But it was held sufficient to exclude the prerogative writs and analogous jurisdiction. My Lord, who delivered the judgment of the Court, remarked ${ }^{138}$ that the authority of Parliament to do so had not been challenged. It is not easy to see how it could have been. I am aware that, on 28th January last, Mr. Justice Beetz, speaking in A.-G. Canada v. Canard, remarked that: ${ }^{184}$

[W] hile Parliament has the power to establish Courts for the administration of the laws of Canada, it does not necessarily follow that it can clothe a Minister, or any official or board of a non-judicial nature, with all the functions of a superior Court; the powers of Parliament are limited by the wording of s. 101 of the British North America Act, 1867, as well as by the federal and fundamental nature of the Constitution which implies an inherent and entrenched jurisdiction in the Courts to adjudicate in constitutional matters.

This is a dark and mysterious warning, in a case in which the Supreme Court upheld the power of Parliament to vest in a Minister of the Crown the administration of the estates of deceased Indians. The dictum does not really offer a criterion which enables us to know which of various persons declared by federal statute to be judges of courts really are judges, and which are mere officials in disguise. I think (as my Lord and his brethren appear to accept for most purposes) that we are constitutionally unprotected against federal privative clauses.

But now I invite my Lord and others to consider various hypotheses as to provincial legislation. By section 96 of the Act of 1867, judges of "the Superior, District, and County Courts in each Province", with immaterial exceptions, are to be appointed by the Governor-General of Canada. So a provincial legislature can create, but not fully constitute, a superior court.

Suppose in the first place that a provincial legislature were to enact, flatly and in express terms, that a certain board or tribunal, whose members were not appointed by the Governor-General"1ss "shall be a superior court". If that were to be valid, this body would enjoy the unique attributes which I have described earlier. It would be free from the control of the ordinary courts. It would have the rare and ultimate power of deciding, for itself and conclusively, the extent of its own jurisdiction. That would be the principal result and obvious purpose of the statute.

Now a provincial legislature which proceeded in so brazen a fashion would quickly find its enactment held uitra vires, for it would have done explicitly the very thing expressly forbidden by s. 96 of the 1867 Act. Obviously it will prefer to frame its legislation in less flagrant terms, - to keep a lower profile, as the saying goes. Can its statute then stand on a better footing if,

182 [1972] S.C.R. 821.

183 Id. at 825.

134 (1975) 52 D.L.R. (3d) 548 at 572 . This is said to be an "obvious qualification" on Parliament's power "constitutionally [to] oust the jurisdiction of provincial Courts in these as well as in other federal matters and vest it in a federal agency". This power seems to be accepted by the whole bench; Laskin C. J. C., for himself and Spence J., dissenting on other grounds, expressly rejects $s$. 96 of the Act of 1867 as a constitutional limitation on federal legislation (p. 551).

${ }^{135} \mathrm{Or}$ were appointed beforehand for different functions entirely: A.-G. Ontario v. A.-G. Canada, [1925] A.C. 750. 
instead of providing that the board shall be a "superior court" it enacts that the board shall have "jurisdiction to determine its own jurisdiction" in the sense that the board's own determination cannot be collaterally challenged? Is not this the very same thing as declaring the board to be a superior court? And if the provincial legislation takes a form more indirect still, and addresses itself not to the board but to all other courts, with the command that none of them shall question the acts or orders of the board - or acts or orders bearing certain formal indicia - is not this again the very same thing in another guise?

In all three cases, I submit, the provincial legislation has in substance attempted to endow the provincial board with a legal attribute which, before and above every other, is by first constitutional principles, unique to the superior courts. That attribute indeed underlies the superintending and reforming power which, in Séminaire de Chicoutimi v. A.-G. Quebec (1972) ${ }^{130}$ the Supreme Court held could not be committed to any but a court constituted with a section 96 judge.

With the greatest respect to my Lord's extrajudicial writings, ${ }^{137}$ it seems to me mistaken to look at the matter as if it were purely a question of the provincial legislative power to abolish superior courts and to curtail their powers. I am prepared to assume for the moment that the provincial legislature can abolish the provincial superior courts outright, or abolish the prerogative remedies, or the jurisdiction of the superior courts to give relief by way of damages, declaration, or injuction. None of these hypotheses, however well founded they may be, entails the conclusion that the provincial legislature can endow its officers, boards, or inferior courts with the attribute that their acts or orders shall be immune from collateral challenge in whatever courts, federal or provincial, happen to survive, and in the course of the administration by those courts of whatever jurisdiction, civil or criminal, remains to them. It is one thing to admit a power to curtail the jurisdiction of the superior courts. It is another to admit a power to turn inferior into superior courts.

If, therefore, section 96 of the Act of 1867 means anything at all, it must I think mean this at least. It is not open to the legislature of a Canadian province to place within the jurisdiction of any body save a court whose judges are appointed in accordance with section 96, either the determination of its own jurisdiction, or, a fortiori, the jurisdiction of any other body; - in this sense, that a determination so made would not be collaterally challengeable. ${ }^{138}$ I would go further, and say that even an attempt to invest such an attribute in District and County Court judges would so transform their status as to make their functions different from those to which the Governor-General had previously appointed them, and require at least a new federal Commission. ${ }^{139}$ For the provincial legislature would be turning inferior into superior courts.

I would not deny that, in an administrative sense, everyone must constantly make decisions as to his own jurisdiction and that of everyone else. If someone asks me to act, there are only two possibilities. Either I act or I refuse. Declining implies a position every bit as much as acting. That is the human

186 [1973] S.C.R. 681.

${ }^{187}$ Laskin, Canadian Constitutional Law, 4th ed., p. 784 ff. at 788: "After all, there is no constitutional principle which forbids curtailment of superior court jurisdiction." That is in the "Note on Municipal Tax Assessment and Section 96".

$138 \mathrm{Or}$, at very least, challengeable directly by the prerogative remedies or similar methods. But that would involve me in departing from my hypothesis that the prerogative remedies can be abolished.

139 In accordance with A.-G. Ont. v. A.-G. Can., supra, n. 135. 
condition. That is the existential dilemma. That is why an inferior court has no choice but to decide every question of law and fact upon which its own jurisdiction depends. That is so whether its jurisdiction depends on a rule of common law, or the meaning or even the validity of an enactment. Such was the decision of the Supreme Court of Canada in the Chicoutimi case to which I have just referred, upholding the right of an inferior court judge to rule as to the constitutional validity of an enactment purporting to confer jurisdiction upon him. The fallacy, as I see it, arises when it is assumed that, merely because a man has no choice but to rule for or against his own jurisdiction, that choice, whatever it may be, must be free from correction if he errs. ${ }^{140} \mathrm{My}$ point is that jurisdictional error is, and constitutionally must be, the sole prerogative of the superior courts. Everyone else's must be open to correction by competent courts, employing such remedies as may lawfully be theirs. My position, I submit, is implicit in Toronto v. Olympia Edward Recreation Club Ltd. (1955), ${ }^{141}$ where all nine judges were agreed on this at least, that a provinciallyappointed board could not adjudicate conclusively as to the municipal assessor's jurisdiction.

I have so far assumed an unlimited provincial legislative authority to abolish the superior courts or particular remedies. But is this power wholly free from any plausible constitutional objection? I ask this question, but do not presume to answer it. Prima facie the legislatures of the Canadian provinces certainly enjoy the necessary power under head 14 of section 92 of the 1867 Act. Still, they are bound to exercise this power, like all others, in such manner as not to infringe any other constitutional rule. Join me, if you will, on a flight of fancy. Suppose it were to be held (for example) that the elimination of the prerogative remedies as a method of controlling usurpation of public office $^{142}$ and of jurisdiction, would necessarily result in such a transformation of the position of provincial public authorities as to make them, de facto if not de jure, laws unto themselves, in a manner inconsistent with section 96 . It is certainly true that when particular bodies are singled out and exempted from the prerogative writs even for jurisdictional excesses, that seems to place them in a privileged position ordinarily associated with the status of a superior court. Suppose, as I say, that total or partial abolition of prerogative remedies generally or in favour of particular tribunals - were held ultra vires as an indirect means of turning inferior bodies de facto into superior courts. What is there in this of which a province could fairly consider itself aggrieved? Not, certainly, that its tribunals could no longer effectively usurp jurisdiction. That, I have suggested already, is, constitutionally, not the prerogative of inferior courts. What then would be the complaint? Simply that the courts had drawn the constitutional line in a more practical place.

But it will be said that the same argument was advanced, and failed, in the leading appeal, Labour Relations Board of Saskatchewan v. John East Iron Works. ${ }^{143}$ There it was urged that a privative clause turned the Labour Relations Board into a superior court. That was rejected, but Viscount Simonds pointed out that it seemed clear that that privative clause "would not avail the tribunal if it purported to exercise a jurisdiction wider than that specifically entrusted to it by the Act." That case is therefore no authority on the constitu-

140 Exactly this mistake seems, on any but a rather artificial reading, implicit in Ville de Montreal v. La Cour Provinciale [1974] C.S. 66, which seems to stand the Chicoutimi Case on its head.

141 [1955] S.C.R. 454.

142 Accordingly as the doctrine allowing effect to the acts of de facto officers is more generous, so quo warranto becomes more critical.

143 [1949] A.C. 134. 
tional validity of a privative clause insulating jurisdictional excess from the prerogative writs. This remains open. Chief Justice Rinfret in 1953 virtually dared the Attorney-General for Quebec to argue the point, ${ }^{144}$ and left little doubt what his answer would be. I would welcome so promising an invitation from my Lord the present Chief Justice. For I think that the liberty of the subject greatly depends on the result. 